\title{
Türkiye'de 6360 Sayılı Yasa Kapsamında Mahalle ve Köy Yönetiminde Yaşanan Değişim ve Dönüşüme Muhtarların Bakışı
}

\author{
Neighborhood Representatives' View about Change and Alternation Which Are Seen in Local and \\ Village Government in Turkey within the Scope of 6360 No. Act
}

\author{
YETER AVSAR \\ Dr, KSÜ, İ̈BF, Kamu Yönetimi Bölümü \\ y.cicek_01@hotmail.com \\ https://orcid.org/0000-0001-7190-7150
}

Makale Başvuru Tarihi: 11.11.2020

Makale Kabul Tarihi: 20.12.2020

Makale Türü: Araştırma Makalesi

\section{ETHEM TAS}

Prof. Dr., KSÜ, IIBF, Kamu Yönetimi Bölümü

i.ethem.tas@gmail.com

https://orcid.org/0000-0003-0958-7306

Anahtar
Kelimeler:
Mahalle Yönetimi,

Köy Yönetimi,

Muhtar,

6360 Sayılı Yasa,

\section{ÖZET}

Son yıllarda Türkiye'de katı merkeziyetçi teşkilatlanma yapısını yumuşatmak ve yerelde hizmet sunumunda etkinliği sağlamak adına yerel yönetimler alanında kapsamlı çalışmalar yapıldı̆̆ı görülmektedir. Bu çalışmaların başında ise 6360 Sayılı Yasa gelmektedir. Bu yasa büyükşehir olan illerde büyükşehir belediyelerinin hizmet alanlarını ilin mülki sınırları olarak genişletirken köyleri de tüzel kişiliği olmayan mahalleye dönüşü̈rmüşı̈̈r. Ayrıca bu süreçte; belediyeler il mülki sınırlarından sorumlu tutulurken, köylerin kırsal alanlara yönelik sorumluluklarını belediyelere devretmeleri, köylerin mahalleye dönüşmesi bağlamında yükümlülük yüklenmeleri ve muhtarların eskiye nispeten değișen konumları sorgulanmaya başlanmıştır. Kırsal alan yönetiminde önemli bir pozisyona sahip olan muhtarların bu konuya bakışı çalışma için önem arz etmektedir. Bu kapsamda çalışma genelinde 6360 sayıl yasayla eski köylerin/yeni mahallelerin durumu ve mahalle yönetimine dair mevzuat irdelenmiş, çalışma özelinde ise tüzel kişiliğe sahip köy muhtarıken 6360 sayıl yasayla tüzel kişiliği olmayan mahalle muhtarı olarak farklı bir konuma getirilen muhtarların durumu teorik çerçevede incelenmiștir. Sonrasında 6360 sayıl yasayla Büyükșehir Belediyesi statüsü kazanan illerde köy durumunda olan yerleşim yerlerinin mahalle yönetimine dönüsmesi sürecine nasıl baktıklarını ve bu süreci nasıl karșıladıklarını ortaya koymak amacıyla buradaki muhtarlara nicel araștırma tekniklerinden biri olan anket yöntemi uygulanmıştır. Çalışmanın sonunda muhtarların bu sürece farklı yaklaşımları/bakış açıları/beklentileri olduğu tespit edilmiş ve elde edilen bulguların yorumlanmasından hareketle eski köy/yeni mahalle muhtarlarının sorunları belirlenmiş ve bu sorunların aşılması için muhtarların bu yeni duruma ayak uydurmalarına imkân verecek derecede belli bir ölçüde serbestiyet, temsiliyet gücünün artırılması ve mali imkânların kazandırılması gibi öneriler sunularak literatüre katkı sağlanmıştır. Ayrıca 6360 sayll Yasa sonrası oluşan bu eski köy/yeni mahallenin yeni duruma uyum sağlaması için ilgili mevzuatta bazı değişiklikler önerilerek yaşanan sorunlara çözüm üretilmeye çalışılmıştır.

\section{ABSTRACT}

Keywords:

It is seen that the comprehensive studies have been made in the field of local governments in order to soften the structure of strict centrist organization in Turkey and to provide the efficiency in serving locally in the recent years. 6360 No. Act is the main of these studies. While the act expanded the metropolitan municipalities' service area in the metropolitan cities as the city's administrative border, it changed the villages as the neighborhood without legal entity. Moreover, in that process; while the municipalities are held responsible for the provincial administrative borders, it started to be questioned that the villages transfer their responsibles for the rural areas to the municipalities, the villages undertake the responsibility in the context of turning into the neighborhood and the neighborhood representative's position changes compared to before. The view of neighborhood respresentatives with an impportant position in the government of rural areas about this issue has importance for this study. In this context, the legislation related to the situation of old villages/ new neighborhoods and to the government of neighborhood was examined with 6360 No. Act
6360 Numbered Law. 
throughout the study and the situation of neighborhood representatives that was taken into a different situation as a neighborhood representative without the legal entity with 6360 No. Act while they had been the neighborhood representative of village with the legal entity was reviewed within the theoretical framework as specific to the study. After that, a survey method was implemented as one of the quantitative research techniques to these neighborhood representatives in the purpose of revealing how they think about the process that the settlements in village situation in the provinces which gained the status of Metropolitan Municipalities with 6360 No. Act turned into the neighborhood government and how they accept this process. It was determined at the end of the study that the neighborhood representatives have the different approaches/ viewpoints/ expectations on this process and the problems of old/new neighborhood representatives were determined from the point of interpretation of findings which were obtained, and it was contributed to the literature as the suggestions such as increasing the liberty, representation power at a certain level and providing the financial opportunities to the extent to provide an opportunity for the neighborhood representatives to adapt to this new situation were suggested in order that these problems are overcome. Moreover, the solution for problems was tried to be made with the suggestion of some changings in the relevant legislation in order that this old village/new neighborhood adapts to this new situation that it was formed after 6360 No. Act.

\section{GİRIŞ}

Türkiye'de yönetimin örgütlenmesinin temel dayanağı 1982 Anayasasının 123. maddesinde ortaya konulmaktadır. $\mathrm{Bu}$ maddede "idare; kuruluş ve görevleriyle bir bütündür ve kanunla düzenlenir. İdarenin kuruluş ve görevleri, "merkezden yönetim" ve "yerinden yönetim" esaslarına dayanmaktadır." şeklinde belirtilmektedir. Geçmişten günümüze bir değerlendirme yapıldığında Türkiye her ne kadar merkeziyetçi bir yönetim yapısına sahip olsa dahi anayasada da belirtildiği üzere idari yapılanması içerisinde bir tarafta merkezi yönetim bulunurken diğer tarafta da yerel yönetimlere yer verilmektedir. Türkiye'de merkezi yönetim başkent ve taşra teşkilatından oluşurken yerel yönetimler belediye, il özel idaresi ve köylerden oluşmaktadır.

Yerel yönetim birimleri halkın mahalli müşterek nitelikteki ihtiyaçlarını karşılayan, tüzel kişiliği bulunan, kendine ait bütçesi ve personeli olan, özerkliğe sahip anayasal kuruluşlardır. Bunlar halkın günlük ihtiyaçlarının karşılanmasında ve yönetime katılımının sağlanmasında önemli birimlerdir. Bundan dolayı yerel yönetimlerin gerek demokratik hayatta üstlendikleri roller gerek halka hizmet sunumundaki faaliyetleri dolayısıyla önemleri her geçen gün artmakta, dünyada meydana gelen gelişmeler ve değişmelere koşut bir şekilde, Türkiye'de de genel anlamda yönetim olgusunda özel anlamda ise yerel yönetimler bünyesinde benzer gelişmeler ve değişmeler yaşanmaktadır. Yaşanan bu gelişmeler ve değişmelerin yönetimi, çağdaş yönetim anlayış1 çerçevesinde günün koşullarına uyumlu hale getirmeye yönelik olduğu söylenebilir. Çağdaş yönetim anlayışı kapsamında yeni yaklaşımlar ve yeni yönetim modelleri dünyada olduğu gibi Türkiye'de de kamu yönetimini etkilemekte ve yapılan tüm reform hareketleri için bir temel oluşturmaktadır. Yine AB'ye uyum çerçevesinde yapılan değerlendirmeler ve son dönem yerel yönetimlerin yapısındaki değişim sonucunda Türkiye özelinde yerel yönetimler alanında kapsamlı çalışmalar yapılmaktadır. Ayrıca Türkiye'de gerçekleşen reform çalışmalarında ve yapılan düzenlemelerde amaç, etkin ve verimli olacak şekilde hizmet kalitesini artırmak; vatandaş memnuniyetini sağlayacak şekilde şeffaf, açık, hesap verebilir ve vatandaş odaklı olmak; yine vatandaşın yönetime etkin katılımını sağlamak ve artan taleplerine optimal düzeyde karşılık vermektir. Bu amaçlar dâhilinde yapılan düzenlemelerin başında ise 6360 Sayılı "On Dört İlde Büyükşehir Belediyesi ve Yirmi Yedi İlçe Kurulması İle Bazı Kanun ve Kanun Hükmünde Kararnamelerde Değişiklik Yapılmasına Dair Kanun" gelmektedir. Bu yasa büyükșehir olan illerde büyükşehir belediyelerinin hizmet alanlarını ilin mülki sınırları olarak genişletirken; bir yerel yönetim birimi olan ve tüzel kişiliği, kendine ait bütçesi ve personeli, ayrıca özerkliği bulunan köyleri de tüzel kişiliği olmayan merkezi yönetim birimleri ile yerel yönetimler arasında temsilci/aracı bir birim olan mahalleye dönüştürmüştür. Bu noktada çalışmanın araştırılmaya değer yönü yani özgünlüğü ortaya çıkmaktadır.

Buradan hareketle Türkiye'de bir yerel yönetim birimi olarak köylerin ve ne bir yerel yönetim ne de bir merkezi yönetim birimi olan mahallelerin mevcut durumu hakkında ve bunların muhtarlık yapılanması hakkında bilgi vermek çalışmanın amaçlarından birini oluşturmaktadır. Çalışmanın bir diğer amacını ise, 6360 sayılı yasayla Büyükşehir Belediyesi statüsü kazanan illerde köy yönetimine sahip yerleşim yerlerinin mahalle yönetimine dönüşmesi ile buradaki muhtarların bu sürece nasıl baktıklarını ve bu süreci nasıl karşıladıklarını ortaya koymak oluşturmaktadır. 


\section{MAHALLE, KÖY YÖNETIMİ VE MUHTARLIK BİRIMİ ÜZERINE}

Yerel yönetim birimlerinden biri olan ve kırsal alanlarda yer alan "köy yönetimi ve muhtarlıkları" ile ne bir merkezi yönetim ne de bir yerel yönetim birimi olan ve kentsel alanlarda yer alan "mahalle yönetimi ve muhtarlıkları" yaklaşık yüz yıldır Türkiye'nin idari yapılanması içerisinde yer almaktadır.

Türkiye'de bu süreçte idari anlamda pek çok değişim yaşanmış ve bu yapılanmalar süreçten yakından etkilenmiștir. Özelikle kentleşme özelinde yaşanan demografik ve ekonomik değişimler, toplumsal gelişmeler ve küreselleşme sonucu yönetim alanında yaygınlık kazanan modern yönetim yaklaşımları, mahalle ve köy yönetimi ile muhtarlık birimleri de dâhil olmak üzere tüm idari yapılanmada bir değişim ve dönüşüm yaşatmıştır. Bu birimler hakkında detaylı bilgi vermek gerekirse;

Mahalle günümüzde farklı ve çeşitli unsurları içerisinde barındıran, kısacası dinamik bir kavram olmaktadır. Tarihsel ve geleneksel süreçte yakınlık ve komşuluk gibi kavramları direkt akla getiren mahalle; ortak bir tarihsel geçmişe sahip, yerel duygu, bilinç, temsil, katılım, demokrasi gibi kavramlarla bütünleşen, ortak toplumsal ve ortak olarak kullanılan mekânın özelliklerini yansıtan, ortak iş yapma/faaliyet alanı ve paylaşılan ortak çıkarlar gibi daha da çeşitlenebilecek olgularla ifade edilebilmektedir. Bu sayılan her bir unsur mahalle kavramının bir özelliğini yansıtmaktadır. Bunlara ek olarak mahalle, toplumsal bir örgütlenme, ortak davranışların belirleyicisi, bir sosyal doku olarak, özellikle 21. yy ile birlikte kentsel yenileme programlarında ve şehircilikte ortaya çıkan yeni planlama yaklaşımlarında, topluluk ve mekân duygusunu geliştirici kamusal alanların tasarımında önemli bir işlevsel alan olarak da tanımlanmaktadır (Bayramoğlu Alada, 2002:1).

Çalışmanın temel amacı doğrultusunda mahallenin yönetsel yapıda yer alan bir birim olması sebebiyle "mahalle yönetimi" tarihsel süreç içerisinde değerlendirildiğinde; Türkiye, birçok uygarlığa ev sahipliği yapmış bir coğrafyada bulunmakta ve bundan dolayı Türkiye'nin bulunduğu coğrafyanın köklü bir yerleşim tarihi ve bununla birlikte köklü bir yönetim tarihi bulunması kaçınılmaz olmuştur (Bek, 2013:1- 2). Bu kapsamda Türkiye'de merkezi yönetim ve yerel yönetim olmak üzere ikili bir teşkilat yapısından söz etmek mümkün olmaktadır. Merkezi yönetim devlet tüzel kişiliğinde yapılanmış olup, geleneksel yönetim yapısının temelini oluşturmaktadır.

Türkiye'de yerel yönetim teşkilat yapısını ise il özel idaresi, belediye ve köyler oluşturmaktadır. Türkiye'de Büyükşehir belediye yapılanması 1984 'ten itibaren Türkiye'nin teşkilat yapısında yer almaya başlamıştır. İl özel idaresi ve belediyeler Tanzimat'tan sonra idari reformlarla ve Fransa örneğiyle yönetim sistemimizde var olmaya başlamışken mahalle ise, Türk toplumunun yerleşme düzeninin, mali, siyasi, toplumsal ve idari ihtiyaçlarının bir sonucu olarak tarihsel süreçte oluşmuş ve kendiliğinden gelişmiştir. Türk Kamu Yönetim sistemine bir yönetim birimi olarak Tanzimat'tan önce giren mahalle yönetimi, Tanzimat ile oluşturulan diğer birimlerle yeniden ele alınmış, Cumhuriyet döneminde yönetsel kimliği belirsiz hale gelirken, geleneksel ve sosyal bir birim olarak varlığını sürdürmeye devam etmiştir. Mahalle, kentsel alanlarda yerel düzeyde örgütlenmenin ilk basamağı olup ancak bu örgütlenmenin yerel bir örgüt olup olmadığı ve hatta yönetsel bir birim olup olmadığı tartışmalı konular arasındadır. Bilinen ve kabul edilen, üzerinde görüş birliği bulunan durum ise mahallenin bir toplumsal örgüt olduğudur. Ülke çapında düşünüldüğü zaman sosyal ve yönetsel en küçük fakat en yaygın birim olarak kamu yönetimi sisteminde yer almaktadır. Bunu ülke genelinde yapılan mahalle muhtarlığı seçimlerinde görmek mümkündür. Bu doğrultuda mahalle, yerel yönetimler, demokrasi ve halk katılımı noktasında ayrıca kent kültürü ve kentle bütünleşme, kenti benimseme anlamında potansiyel imkânlar sunan bir yerleşim yeri olduğu görülmektedir (Eryılmaz, 1988:465; Kavruk, 2004:1-2).

Osmanlı devletinde mahallenin, seçme ve seçilme hakkını vergi miktarına yani servete bağlayan nizamnamelerin çıkarılması ve mahalle sandıklarına el konulmasıyla mahallenin yapısı bozulmaya başlamış, bu tür düzenlemeler mahallenin çöküşünü hızlandırmıştır. Çünkü mahalle sandıkları, mahalleyi kendi kendine yeten, kendi gelirini yaratan yönetsel ve örgütsel bir birim yapmaktaydı. Bu açıdan mahalleler, toplumsal dayanışma, sorumluluk duygusunun geliştiği, homojen, kendi gelir ve giderini oluşturabilen, kendini yönetebilen geleneksel bir kurum olmaktaydı. Özerklik, demokratiklik, katılımcılık, hemşehrilik bilinci yaygın olarak görülen Osmanlı mahalleleri bir yerinden yönetim birimi gibi çalışmaktaydı. Osmanlıda muhtarlık kurumunun (1829) oluşturulmasıyla birlikte devlet mahalleye el atmış ve zenginlerin idaresi ile mahalleler yönetilmiştir. Bunun devamında daha sonra 1854 yılında bir yerel yönetim biri olan belediyeler oluşturulmuştur ve bu durum mahalle yönetimlerini etkilemiştir. Çünkü oluşturulan belediyeler bir yönetsel kurumun adı olmakta ve yerleşim yerlerinde aidiyet kurumla değil, mekânla ilgili olmaktadır. Buradaki yönetim türü mekâna nitelik katan unsurlardan biri olmaktayken mahalleler ise, bir mekân olmakta ve toplumla ve mekâna olan aidiyet duygusu geniş ölçüde yer bulmaktadır. Mahalleyi belediye gibi sadece yönetsel yapıdan farklı kılan şey 
burada ortaya çıkmakta ve mahallelerin yönetsel kimliklerinden çok bir yerleşim merkezi ve toplumsal dayanışma/ yaşam yeri olması temel özelliği ortaya çıkmaktadır. Ancak büyükşehirlerin giderek yaygınlık kazandığı günümüzde mahalle/mahalle yönetimleri de geleneksel anlamını yitirmekte ve kentlilik bir aidiyet unsuru haline gelmektedir (Kavruk, 2004:5).

Anayasal düzenlemeler kapsamında mahalle yönetimine bakıldığında, Osmanlı döneminde ilk anayasal metin olan 1876 tarihli Kanuni Esasi'de herhangi bir hüküm yoktur. 1921, 1924, 1961 ve günümüzde yürürlükte bulunan 1982 anayasası da mahalle yönetimine dair hüküm barındırmamaktadır. Ancak mahalle yönetiminin organı olan mahalle muhtarının köy yönetimi organlarından olan köy muhtarının seçiminde izlenen yöntemlerin izlenmesi gerektiğine dair kanunun olduğu görülmektedir.

Mahalle yönetimlerinin yasal dayanak bulduğu metin ise 1944 tarihli 4541 sayılı "Şehir ve Kasabalarda Mahalle Muhtar ve İhtiyar Heyetleri Teşkiline Dair Kanun" dur. İlerleyen yıllarda mahalle yönetimlerinin durumlarını iyileştirmeye yönelik girişimlerde bulunulmuştur. Bu kapsamda 1992 yılında Mahalle Muhtarlığı Kanun Tasarısı ve eski tasarının biraz daha genişletilmiş hali olan 1997 tarihli Mahalle Muhtarlığı Kanun Teklifi zikredilebilir. Akabinde 1998 tarihli Yerel Yönetim Kanun Tasarısında da mahalle yönetimlerine yönelik maddelere yer verilmiş ancak, ne bu tasarı ne de öncekiler kanunlaşabilmiştir. Bu düzenlemelerin gerekli ancak etkili ve yeterli olmadığı söylenebilmektedir. Daha sonra 2005 tarihli 5393 sayılı Belediye Kanununun 9. maddesinin de mahalle yönetimine yer verdiği görülmektedir.

Günümüzde mahalle yönetimleri kentsel alanlarda halka en yakın yönetsel birim özelliğini korumakla birlikte seçimle göreve gelen organları olmasına rağmen kendilerine ait bir tüzel kişilikleri, bütçesi bulunmamakta ve yerel yönetimlerle merkezi yönetim arasındaki temsilci niteliğinde olduğu görülmektedir. Mahalle yönetimleri tarihsel süreç içerisinde kendilerine farklı zamanlarda değişik düzenlemelerle verilen yetki ve görevleri, yerel yönetim ve mülki idare birimleriyle ast- üst ilişkisi içinde görmeye çalışmaktadırlar. Zaten mahalle yönetimleri yerel yönetimler ile merkezi yönetim arasında yer alan ve her iki yapıya da yardımcı olan bir ara kurum olmakta özellikle cumhuriyetin ilanından sonra bu durumun günümüzde de geçerliliğini koruduğu belirtilebilmektedir. Keza Türk Kamu Yönetim sistemi teşkilat yapısına bakıldığı zaman mahalle yönetimlerinin, ne merkezi yönetim ne de yerel yönetimler teşkilat yapısı içerisinde olduğu görülmektedir. Ancak mahalle yönetimlerinin organlarının seçilmiş olması, temsil niteliğinin olması ve halkın kendi kendisini yönetme ilkesini hayata geçirebileceği en uygun birimler olması sebebiyle bu kurumlara yerel yönetimlere benzer bir kurum gözüyle bakılmaktadır. Yine yaptıkları hizmetlerin bazısının köy yönetimlerine benzemesi ve belediyelerle olan ilişkileri de mahalle yönetimlerinin yerel yönetimlerle karıştırılmasına neden olmaktadır. Mahalle yönetiminde yaşanan bu hukuki ve yönetsel belirsizlik ile eksiklikler ayrıca zamanla mahalle yönetimlerini işlevsellikten uzaklaştırmakta geleneksel sistemimizde önemli bir yeri olan mahalle yönetimlerinin yapısına zarar verdiği söylenebilmektedir (Palabıyık ve Atak, 2002:18-19). Özellikle de günümüzde 2012 yılında yürürlüğe konulan 6360 sayılı Büyükşehir Belediye Kanunun ardından belediye sınırlarının il mülki sınırları şeklinde genişlemesi ve bu sinırlar içinde kalan köylerin de mahalleye dönüştürülmeleri bu yeni mahallelerde yönetimsel anlamda boşluklar yaratmış ve zaten eski olan mevcut mahalle kanunu buna çözüm sunamamıştır. Yeni mahallelerin bu sorunları da bu anlamda var olan sorunlara eklendiği görülmektedir.

Görülen bu toplumsal ve yönetimsel sorunlar hep birlikte düşünüldüğünde mahalleler, hâlihazırda dağınık halde getirilen yasal düzenlemelerin ve siyasi/politik dünyanın taşıyıcı bir unsuru ya da onun elinde şekillenen bir olgu olarak ele alınmamalıdır. Tam aksine mahalleler, gündelik yaşamda karşılaşılan sorunların çözümlerine pratik ve düşünsel zenginlikler getiren bir birim olarak varlığını devam ettirmelidir (Bayramoğlu Alada, 2000:152).

Çalışmanın temel sacayaklarından biri olan köyler ise, bir yerleşim ve yönetim birimi olarak Türkiye'nin idari bölünüşünde en alt kademede yer alan birimler olmakta ve bu zamana kadar yapılan köy tanımlarının köyü açıklamaya tam olarak yetmediği ve tek bir öğenin de köyü açıklamada yeterli olamayacağı (Tezcan, 1970:153) ifade edilebilmektedir. Çünkü köyler sosyal, ekonomik, toplumsal anlamda tek tip olmayan ve birbirinden farklı özellik gösteren idari birimler olmaktadır.

Çok farklı coğrafi özelliklere/niteliklere sahip olan Türkiye'de de, farklı köy tiplerinin olması ve her birinin farklı özellik/nitelik göstermesi doğal görünmektedir. Köye yönelik yapılan tanımlar bu kapsamda farklılıkları tam olarak yansıtmada yetersiz kalmaktadır.

1924 tarihli Köy Kanunundan da hareketle köylere yönelik genel bir tanım yapmak gerekirse (Özçağlar, 1995:8); 


\begin{abstract}
"Köyler/Köy Yönetimleri, belirli bir idari sınırı bulunan, bu sinırlar içerisinde yer alan devamlı ve geçici kır yerleşmeleriyle ekonomik faaliyet sahalarından oluşan, nüfusu 2000'den az, tarımsal faaliyetlerin egemen olduğu ve seçimle iş başına gelen muhtar ve ihtiyar meclisinin yönettiği, orada yaşayanların ortak ve müşterek ihtiyaçları olan, tüzel kişilik kazanmış en küçük yerel yönetim birimidir",
\end{abstract}

şeklinde ifade edilebilir. Çalışmanın temel amacı doğrultusunda köylerin yönetsel yapıda yer alan bir birim olması sebebiyle "köy yönetimler" üç kademeli yerel yönetim sisteminin en alt kademesini oluşturmakta ve zamanla değişimler yaşamakla birlikte köy yönetimlerinin 1924 tarihli ve 442 sayılı kanunla yürütüldüğü bilinmektedir. Türkiye'nin idari bölünüşü noktasında, vilayetlere, kazalara, kasabalara ve köylere ayrıldığı bir gerçektir. Bundan hareketle ülkenin temelini köylerin oluşturduğu ve bundan dolayı Köy Kanununun bu gerçeği dikkate alarak yazıldığı görülmektedir (Sarı, 2014:531). Köy Kanunu ile birlikte mahalle yönetimine nispeten köyün yönetsel yönü ortaya konulmakta ve köyün yönetsel bir birim olarak çerçevesinin çizildiği ifade edilebilmektedir. Bu kapsamda kanunda köy tanımlanmakta ve köy/köy yönetimi, belediye teşkilatına sahip olmayan, nüfusu iki bini aşmayan, halkın mahalli ve müşterek ihtiyaçlarını gidermekle görevli ve organları halkın seçtiği kişiler olan, kendine ait bir bütçe ve personele sahip kamu tüzel kişileri şeklinde belirtilmektedir (Kavruk, 2004:17-18). Burada dikkatleri çeken en önemli nokta ise köylerin mali ve idari anlamda serbest karar alıp verme ile kendilerine ait bütçe ve personelinin olması özerkliğinin olduğunun bir kanıtıdır. Ayrıca buna ek olarak devlet tüzel kişiliğinden ayrı bir yerel yönetim birimi olması sebebiyle de tüzel kişiliğinin bulunması köylerin idari yapıda önemli bir noktada yer aldığını göstermektedir.

Köy Kanunu yapıldığı dönemde öncelikli olarak köylerde kalkınma sağlanırsa tüm memlekette kalkınmanın sağlanacağı fikrinden (Sarı, 2014:531) hareket edildiği bir gerçektir. Temel amacın ülke genelinde ekonomik, sosyal, toplumsal gelişmeleri hızlandırmak adına ilk olarak köylerden başlanılması gerektiği düşüncesinin hâkim olduğu görülmektedir. Bu kapsamda köyler önemli bir noktada bulunmakta ve en eski yerel yönetim birimi olması sebebiyle demokratik adımların atılacağı uygun idari birimler olmaktadır.

Ancak Cumhuriyetin ilanıyla birlikte 1930'lu yıllara kadar il özel idareleri yerel yönetim türleri arasında ağırlıktayken, 1950'li yıllarla birlikte meydana gelen değişimler ve özellikle kırdan kente göç belediyelerin ön plana çıkmasını sağlamıştır. Bunlara nispeten köyler ise geçmişi çok uzun yıllara dayanmakla birlikte zamanında il özel idareleri ya da günümüzdeki belediyeler gibi bir işlevi tarihsel süreçte olmamıştır. Yerel yönetim sisteminde belki de en az müdahale edilen alan olarak kalmakta, hatta günümüzde yürürlükte bulunan Köy Kanunun bile asırlık olduğu görülmektedir (Cihangir Çamur, 2002:84; Ozankaya, 1971:31). Buna ek olarak Türkiye'de özellikle de kentleşmiş kesimlerinde köy yönetimlerinin yerini belirlemek günümüzde önemle tartışılan konular arasında olmaktadır.

Yine Türkiye'de yaşanan sosyal, ekonomik ve kültürel değişimle birlikte Köy Kanunun pek çok maddesinin işlevsiz kaldığı ve köye yönelik çoğu hizmetin devletten beklendiği görülmektedir. Köy Kanunu (Sarı, 2014:517) yürürlüğe girdiğinde amaç Cumhuriyet Türkiye'sinde köylerin mevcut geri kalmışlık düzeyini ortadan kaldırmak ve kalkınmış bir köy/köy yönetimi oluşturmaktı. Kanun çıktığı dönemde şartları iyileştirmiş hatta dönemin yapılan en büyük reform çalışmalarından sayılmıştır. Ancak o dönem Türkiye'deki nüfusun yaklaşık \%85'i köylerde yaşarken (Gündüzöz, 2011:124) günümüzde, özellikle 2012 y1lında kabul edilen ve 2014 yerel seçimleri ile yürürlüğe konulan 6360 sayıl1 "On Dört İlde Büyükşehir Belediyesi ve Yirmi Yedi İlçe Kurulması İle Bazı Kanun ve Kanun Hükmünde Kararnamelerde Değişiklik Yapılmasına Dair Kanunla” birlikte bu oranın \%15'lere düştüğü görülmüştür. Köy nüfusu bu süreçte değişmemiş fakat köylerin genel nüfus içerisindeki payı sürekli azalma göstermiştir. Bu durumda bir yerel yönetim birimi olan köy yönetimlerinin işlevselliğini etkilemiş ve Büyükşehir Belediyesinin olduğu alanlarda varlıklarına son verilerek "mahalleye" dönüştürülmesini sağlamıştır.

Yukarıda ifade edilen mahalle ve köy yönetimlerinin muhtarlık birimleri incelenecek olursa; Türkiye'de kentsel alanlarda yer alan mahallelerde ve yerel yönetim birimlerinden biri olup kırsal alanlarda yer alan köylerde, idari yapılanma 1829 'dan beri yani yaklaşı olarak iki asra yakın bir zamandır muhtarlık kurumu üzerinde inşa edilmiştir. Bu doğrultuda Türkiye'de iki tür muhtarlık yapılanması bulunmakta ve köy muhtarları birer yerel yönetim organıyken mahalle muhtarlıkları ise merkez ile yerel arasında aracı bir birim olmaktadır.

Muhtarlık kurumunun ortaya çıkmasını izleyen süreçle birlikte Türkiye özelinde yaşanan kentleşme, demografik değişimler ve yönetimde çağdaşlaşma algısı, tüm kamu yönetimi örgüt yapılarında muhtarlık birimi de dâhil olmak üzere dönüşümü ve değişimi meydana getirmiştir.

2000'li yıllar sonrası yapılan yerel yönetim reformları değerlendirildiğinde yapılan reform çalışmalarının belediye odaklı olduğu görülmekte ve köy ve mahalle düzeyindeki muhtarlık birimi ise geri planda kalmaktadır. 
Tarihsel süreçlerini de incelerken detaylı bir şekilde anlatılan köy ve mahalle muhtarlıkları kendi alanlarında çok eski kanunlarla yetki ve sorumluluklarını yerine getirmekte olduğu, bu alana yönelik yapılan kanun tasarılarının da kanunlaşamadığı detaylı anlatılmıştır. Bu tasarılar muhtarlık birimini iyileştirici ve durumunu geliştirici maddeler barındırmalarına rağmen dönemindeki yoğun eleştiriler nedeniyle tasarıdan öteye gidememiştir.

2012 yılında ortaya koyulan 6360 sayılı yasa da büyükşehir yapılan ilerdeki tüm köyleri kaldırmış ve mahalle konumuna getirmiştir. Dolayısıyla bu illerdeki köy muhtarları köy yönetimine ilişkin yetkilerini kaybederek mahalle muhtarına dönüştürülmüştür. Ayrıca mahalle muhtarlarının geçmişten günümüze oldukça tartışılan ve mevcut olan;

- Yasal düzenlemelerin eksikliği,

- Mevcut tabi oldukları kanunların çok eski olması ve

- Mevcut tabi oldukları kanunların günümüz ihtiyaçlarına cevap verememesi,

- Özlük haklarıyla ilgili pek çok sorunların yaşanması,

- Görevleriyle ilgili yetki alanlarının sınırlı olması,

- Mali anlamda bir bütçelerinin olmaması,

- İdari yapılanmadaki yerlerinin net olmamas1,

- Tüzel kişiliklerinin bulunmaması,

- Bu kapsamda yapılan pek çok düzenlemenin uygulamaya koyulamaması,

gibi sorunların yanında köy muhtarıyken köylerin sahip oldukları tüzel kişiliklerini ve kendilerine ait olan mali özerkliklerini de kaybederek mahalle muhtarlığına dönüşmüş olmaları yeni sorunları ve tartışmaları da gündeme getirmiştir.

Bunlara ek olarak Türkiye'de yaklaşık olarak nüfusun \%80'i kent merkezlerinde yaşamaktadır. Bunlar içerisinde yaklaşık 18 bin köy ve 32 bin mahalle bulunmaktadır (www.e-icisleri.gov.tr, 30.07.2018). Toplamda ise 50 bin civarında muhtar bulunmakta ve halk doğrudan bu kişileri seçmektedir. Halkın doğrudan seçimle belirlediği bu kadar kişinin herhangi bir idari mekanizmadan destek bulamaması demokratik bağları zayıflatmaktadır.

Köylerin ya da köy muhtarlarının birer mahalle yönetimi ve mahalle yönetimi organlarına dönüşmesiyle alakalı durumlarının ne olması gerektiği yönündeki düşünceler ve günümüzde karşılaşılan tüm bu karmaşıklıklarla beraber hala durumları netleştirilmeyen muhtarların günümüzdeki mevcut durumunun tespiti ve iyileştirilmesine yönelik neler yapılabileceğine cevaplar, çalışmanın ilerleyen bölümlerinde Türkiye'de yapılan bir alan çalışmasının sonuçlarının analiz edilmesi ve yorumlanmasıyla verilmesi, planlanmakta ve öngörülmektedir.

\section{6360 SAYILI YASANIN MAHALLE VE KÖY YÖNETIMINE YÖNELIKK GETIRDİĞİ DÜZENLEMELER}

Tarihsel süreç içerisinde büyükşehirlere yönelik genel bir değerlendirme yapıldığında 6360 sayılı yasanın büyükşehirlere yönelik yapılan düzenlemeler içerisinde sonuncusu olduğu görülmektedir. Bu yasa Türkiye'de büyükşehir sisteminde (K1lınç Ürkmez ve Zengin Çelik, 2016:76);

- İdari, mali ve siyasi değişiklikler getiren,

- Kamusal hizmetlerin sunumunda etkinlik ve verimliliği öncelikli şart olarak gören yeni bir süreç başlatan,

- Bütünleşik bir kent yönetim sistemi öngören bir model olarak ortaya konulmuş, özellikle de daha önce dile getirildiği ve incelendiği gibi yönetim temelinde amaçlanan olumlu durumlar yanında olumsuzlukları da gündeme getirmiş ve üzerinde çeşitli tartışmalar ve eleştiriler yapılmıştır.

6360 sayılı yasa ile birlikte gelen, yasanın getirdiği değişikliklerden ve üzerinde en çok durulan konulardan biri de köylerin tüzel kişiliklerinin kaldırılması ve mahalleye dönüştürülmesi ile Türkiye'deki tüm yerleşimlerin kent olarak değerlendirilmesi konusu olmuştur. Bu değişimle birlikte model içerisinde kırsal ve kentsel farkl11ıkların nasıl yeniden yapılandırılacağı da eleştiri konusu olmakta ve tartışmalar arasında yerini almaktadır. 
Yasanın yürürlüğe girmesiyle birlikte Türkiye'de \%77 olan kentleşme oranı $\% 91$ olarak değişmiştir. Henüz kent olabilecek göstergeleri barındırmayan çoğu kırsal alanın kent olarak nitelendirilmesi uluslararası ölçekte yapılacak karşılaştırmalarda yanıltmalara sebebiyet vermesi muhtemel bir unsurdur. Ayrıca bu durum kırsal alan politikaları üzerinde de olumsuz sonuçların ortaya çıkmasına neden olabilmektedir. Nitekim köylerin değişim geçirerek mahalleye dönüşmesi durumunda bu eski köy/ yeni mahallelerin, KÖYDES, Tarım ve Kırsal Kalkınma Destekleri ve AB fonlarının kullanımı kapsamından çıkarılması da söz konusu olmuştur (Gökyurt vd., 2015:23). Bunlardan hareketle 6360 sayılı yasanın kırsal kesime yönelik olumsuz yanlarının yanında olumlu yanları da bulunmaktadır. Yasanın kırsal kesime sağladığı olumlu ve olumsuz yönlerini şu şekilde detaylandırmak mümkündür (Ayyıldız vd., 2016:282-283);

\section{Kırsal kesime să̆ladı̆̆ olumlu yönleri:}

- Yasa ile birlikte 16.561 köy tüzel kişiliğini kaybetmiş ve ilgili belediyelere bağlanarak mahalle haline gelmiştir. 6360 sayılı yasa öncesinde köylere yönelik hizmetler, köyün bütçesinden ve il özel idarelerinin destekleri ile sağlanmakta fakat köy bütçesindeki yetersizlikler ve il özel idarelerinin sorumluluk ve yetkilerinin oldukça fazla olması köylere yönelik bu hizmetlerin tam olarak etkin ve verimli sunulmamasina neden olmaktayd. Bu hizmetlerin artık belediyeler tarafindan yerine getirilecek olması kırsal alandaki yaşam şartlarının iyileştirilmesi açısından önemli görülmektedir.

- Yine yasa öncesi kırsal yerleşim yerlerinde sağlıklı yapılaşmanın ve afet riski olan yapıların denetiminin olmayışı pek çok problemleri de beraberinde getirmekteydi. Ancak yasayla birlikte belediyelerin bu yönde bir hizmet vererek planlı yapılaşma için çalışmaları önem arz etmektedir.

- Öte yandan, il mülki sınırları içerisinde taşımacılık sisteminin tez elden belediyeler tarafindan üstlenilmesi ve kontrol edilmesi de kırsal nüfusa ulaşım noktasında birçok kolaylık sağlamaktadır.

\section{Kırsal kesime sağladı̆̆ı olumsuz yönleri:}

- Türkiye'nin coğrafi yapısı düşünüldüğünde kırsal yerleşim alanları ile kentsel yerleşim alanlarının birbirine olan uzaklığının azımsanmayacak derecede fazla olduğu görülmektedir. İstanbul ve Kocaeli illeri dışında yasanın uygulanmaya başladığı illerin büyük bir çoğunluğu yerleşim açısından dağınık bir yapı sergilemektedir. Bu şekilde belediyelerce yürütülecek hizmetlerin kırsal alana ulaştırılması konusunda sikıntılar mevcut olmakla birlikte su, kanalizasyon ve itfaiye hizmetlerinin yetersiz kalacağı görülmüştür. Belediyelerin hizmet alanı da genişlediği için belediyelerin, kent merkezinden uzaklaştıkça diğer yerleşim birimlerine götüreceği hizmet kalitesinde de azalma olacağı kaçınılmaz bir durumdur.

- Bu yasa ile birlikte belediyelerin hizmet götüreceği alan da genişlemiştir. Belediyelerin kent merkezlerinden uzaklaştıkça uzaktaki yerleşim birimlerine götüreceği hizmet kalitesinin azalacağı aşikârdır. Bu durumda kırsal alanda yer alan mahallelerin ihmal edileceği kaçınılmaz bir durum olacaktır.

- Yasa ile köy bütçesinin kaldırılması köylü devlet işbirliği ile yapılacak çalışmalarında etkinliğini azaltacaktır. 6360 sayılı yasa öncesinde il özel idaresi ya da çeşitli projeler ile köylü devlet işbirliği sağlanarak sağlık ocağı, okul, içme suyu hatlarının döşenmesi vb. birçok çalışma yürütülürken yasa sonrası köylerde yapılacak birçok hizmet ya belediye personeli ya da taşeron firmalara kalmıştır. Köy bütçesi olmaksızın bu işlerin salt belediye tarafindan yapılması kısa vadede mümkün görünmemektedir.

- Mali açıdan zayıf ve zaten borçlu olan ilçe belediyelerinin köy yerleşimlerine de hizmet götürecek olması köy yerleşim yerlerinin belediyecilik hizmetleri açısından ihmal edileceği ve hizmetlerin ne zaman ulaştırılacağı konusunda endişeleri de beraberinde getirmektedir.

- Kırsal kesimde yaşayanlara yönelik su ve atık su ücretleri, emlak vergisi, yapılacak inşaatlara ilişkin proje masrafları ve diğer mali yükümlülükler yansitılacak bu durum geliri düşük olan kırsal nüfusun yaşam standartlarını olumsuz etkileyecektir. Hatta kırsal alanda yaşayanları şehirlere göç etmeye zorlayacağı da düşünülmektedir.

- Yasa öncesi köy tüzel kişiliğine ait olan mera, yaylak, otlak gibi hayvancilıkla alakalı olan araziler belediyelerin mülkiyetine geçmiştir. Her ne kadar yasa buraların kullanımının köylüye ait olduğunu vurgulasa da bu tür yerlerin kiralanma ve satış durumlarının olması, köylerdeki hayvancılık etkinliğinin azalmasına sebebiyet verecektir. 
- Yine yasa ile birlikte köylerdeki bazı tarımsal alanların imara açılma riski bulunmaktadır.

- Sabit hayvancılık yatırımları için (ahır, ağıl, samanlık vs.) proje ve imar izni gerekeceğinden bu durumun da hayvancilığı olumsuz etkileyeceği söylenebilmektedir. Yine yasa kapsamında çevre duyarlılı̆̆ 1 nedeniyle köylerde bulunan ahırların köy dışına çıkartılarak yapılacak olması endişe uyandırmaktadır. 6360 sayılı yasa hayvancılığa ilişkin imar müsaadesi verse de ilerleyen yıllarda ilave yasalarla bu durum sorun yaşatabilecektir.

- Yasayla birlikte "büyükşehir ve ilçe belediyeleri tarım ve hayvancıllk destekleri için her türlü faaliyette bulanabilirler", denilmektedir. Ancak belediyelerin bu tarz hizmetlere yönelik bir alt yapısı mevcut değildir. Çünkü 6360 sayılı yasa öncesinde tarımsal hizmetlere yönelik İl Özel İdareleri ve Köy Hizmetleri İl Müdürlükleri çeşitli politika ve destekleri olmaktaydı ve yeni süreçle birlikte bu birimlerin kaldırılmasıyla uzun vadede sıkıntılı süreçlerin yaşanacağı ileri sürülmektedir.

6360 say1lı yasa ile köylerin 16.561 köy, Türkiye'deki köylerin \%47'si mahalleye dönüştürülmesi basit bir idari değişiklik olarak ele alınamayacak nitelikler taşımaktadır. Birer yerel yönetim birimi olan ve tüzel kişiliği bulunan köylerin gelenek ve tarihsel geçmiş üzerine kurulmuş oldukları dikkate alınarak, çalışmanın temel vurgularından biri bu olması sebebiyle çalışma bu yönde dikkatleri toplamaktadır.

6360 sayılı yasayla açıklığa kavuşturulması gereken bir diğer durum ise nüfusu 500'ün altında kalan yerlerdir. Çünkü 6360 sayılı yasayla belediye sınırları içerisinde nüfusu 500'ün altında kalan yerlerde mahalle kurulamayacağ 1 belirtilmiş ve kapatılan köylerin nüfusunun önemli bir kısmının 500'ün altında kaldığ görülmüştür. Toplamda 16.541 köy içinden 5536'sının nüfusu 500'ün üzerindedir. Yani oran olarak bu durum köylerin \%33,46026'sına tekabül etmektedir. Geri kalanı ise 500'ün altındadır. Köylerin nerdeyse \%70'inin nüfusunu 500'ün altında kalmakta ve bunun için nasıl bir uygulama devreye sokulacağı da belirsizdir. Çünkü yasal anlamda bu yerlerin mahalle olmaması gerekmektedir. Birleştirilmeleri noktasında da pek çok kaygıları beraberinde getirmektedir. Çünkü köyler pek çok farklılıkları bünyesinde barındıran birimler olmakta ve birleştirilmeleri durumunda da bu farklılar göz ardı edilebilecektir. Niteliksel olarak bazı sıkıntıların oluşması da öngörülmektedir.

Köy yönetimleri sahip oldukları tüzel kişiliklerinden dolayı farklı hak ve ayrıcalıkları kullanma hakkını elde eden bir yerel yönetim birimi olmaktadır. Ancak bu yasa ile birlikte köylerin tüzel kişiliğinin kaldırılıp mahalleye dönüştürülmesi ve tüm mallarının büyükşehir belediyesine devredilmesi durumu (Dik, 2014:75; K1lınç Ürkmez ve Zengin Çelik, 2016:76; www.yayed.org);

- Köylerin tarihsel birikimi ile geliştirdikleri pratikleri ve ortaklık duygusunu,

- Demokratik katılım mekanizması açısından yüksek önem taşıdığı yargısını,

- En eski bir yerel yönetim birimi ve

- Kendilerine ait mal varlıklarının ve personelinin olması durumunu,

- Kırsal alanlara özgü olan tarım ve hayvancıl1k sektörünün geleceğini,

- Anayasal haklar ve hukuki niteliği açısından da sorgulanmasına neden olmuştur.

6360 sayılı kanunun eski köylere/yeni mahallelere getirdiği düzenlemelerle birlikte önce anayasaya uygunluğu noktasında çeşitli tartışmaların yapıldığını ve bu konuda açıklama yapılmasının da çalışma kapsamında yararlı olacağı görülmektedir. Bu kapsamda iki farklı düşüncenin olduğu görülmektedir. Bazı yazarlara göre köylerin tüzel kişiliklerinin kaldırılması ve mahalle olarak konumlandırılmaları anayasanın 127. maddesine aykırılık oluşturmaktadır. Anayasal bir birim olan köylerin ancak anayasal bir düzenlemeyle kaldırılmasının uygun olacağı belirtilmektedir. Ancak bazı yazarlar ise anayasa mahkemesinin denetiminden geçmiş olan böyle bir düzenlemenin anayasaya aykırı olmadığını ifade etmişlerdir (Tekin, 2016:1249).

6360 sayılı yasa kapsamında köylerin mahalleye dönüştürülmesi, köylerin idari yapısında pek çok değişikliklere sebep olacağını ortaya koymaktadır. Her şeyden önce Türkiye tarihinde uzun bir geçmişe sahip olan köylerin bu yeni yasayla mahalle olmasındaki durumunu ve bu süreçte köy muhtarıken mahalle muhtarı olan muhtarların pozisyonlarını ayrıntılı olarak açıklamakta yarar vardır.

İlk olarak köylere yönelik tanımlamalarda niteliksel ayrım büyük önem taşımaktadır. Köyü köy olarak bırakmada, değiştirmede ya da kentsel bir alan haline getirmede göz önünde tutulması gereken ilk şey köy olgusundan neler anlaşıldığıdır. Köylerin diğer yerleşim yerlerine nispeten sosyolojik bir yönünün olması ve 
sosyolojik açıdan tanımın farklı olması önemli bir durumdur. Bu kapsamda diğer yerleşim birimlerinden ayrıştığı nokta köyün, toplumsal yapıda gördüğü tarımsal üretimdir. Kırsal bir nitelik taşıyan ve tarımsal üretim ve hayvancılığın yapıldığı yerleşme birimidir (Dik, 2014:89). Bu kapsamda ilgili bölümlerde ayrıntılı olarak incelenen 1924 tarihli 442 sayılı Köy Kanununda da bu durum ifade edilmiştir. Mahallelere yönelik tanımlamalarda ise çok ayrıntılara inilmemekte, 5393 sayılı Belediye Kanununda mahalle, belediye sınırları içerisinde yer alan, ortak ihtiyaç ve öncelikleri benzer özellikler gösteren ve sakinleri arasında komşuluk ilişkisi bulunan insanların yaşadığı idari birim olarak ifade edilmektedir. Mahallelerin de yapısının ve görevlerinin yer aldığı kanun 1944 tarihli ve 4541 sayılı Şehir ve Kasabalarda Mahalle Muhtar ve İhtiyar Heyetleri Teşkiline Dair Kanundur (Gözler ve Kaplan, 2016:215).

Köy muhtarı kırsal yerleşim biriminin başı, yasal ve tüzel kişiliğin temsilcisidir. Bir yerel yönetim birimi olmasından dolayı tüzel kişiliği temsil etmekte, köy yönetimine ait bütçe ve personel üzerinde söz sahibi olmakta ve özerklikten yararlanmaktadır. Ayrıca köy muhtarı köyle ilgili herhangi bir iş olması durumunda köylüye bunu yaptırabilmektedir. Mahalleler ise tarihsel olarak çok eski birimler olsa da, pek çok kişi tarafında aynı köyler gibi bir yerel yönetim birimi olarak bilinse de, mahallenin organları da köyün organları gibi (muhtar, ihtiyar heyeti) adlandırılsa da, mahalleler tüzel kişiliğe sahip olmayıp hukuki anlamda köylerle karşılaştııılamazlar. Köyler gibi hak ve yetkilere sahip olmadıkları gibi, hukuki işlem yapamaz ve hak ve borç altına giremezler. Dolayısıyla hukukun nezdinde mahallelerin herhangi bir yaptırımı yoktur. Ayrica mahalle muhtarlığ giren konularda onlara yardımc1 olmaktır bundan dolayı (Kaypak, 2013:259) gerekli yerlerde yasal olarak mahalleyi temsil de edemez. Ayrıca mahalle muhtarı mahalleye yönelik işlerde ancak mahalleliye gönüllülük esasına göre bunu yaptırabilmektedir (Gözler ve Kaplan, 2016:215; Dik, 2014:89).

Yeni mahallelerin 6360 sayılı kanunla birlikte elde ettikleri bazı olumlu ve olumsuz durumları şu şekilde sıralamak mümkündür (www.academia.edu, 22.10.2018):

\section{Olumlu durumlar kapsaminda;}

- Köylere yönelik belediye hizmetleri ilçe belediyeleri ya da büyükşehir belediyesi tarafindan verilecek olup; su, kanalizasyon işleri, toplu taşıma hizmetleri, köyün meydan ve anayolları ile köyü ilçeye bağlayan yolların yapımı, bakım ve onarımı, temizliği, karla mücadele çalışmaları ve buralardaki reklam ve ilân işleri ildeki büyükşehir belediyesince; büyükşehir belediyesi yetki alanı dışında kalan imar işleri ile yollar ve sokaklara ilişkin hizmetler, çöp toplama, evlendirme, cenaze defin gibi hizmetler ise ilçe belediyesince yapılacaktır.

\section{Olumsuz durumlar kapsaminda;}

- Sosyolojik bir birim olan köyler mahalleye dönüşünce bu özelliğini kaybedecek ve bir kimlik problemi oluşacaktır. Köylerin tüzel kişiliği kaldırıldığından taşınmazları üzerinde de belediyeler söz sahibi olacağ için bu durum sonraki dönemlerde birtakım sorunlara kaynaklık edebilecektir.

- Köylerin mahalleye dönüşmesiyle mali yükümlülükleri (emlak vergisi, köye yönelik harcama paylarına katılım, çöp vergisi, su vergisi) artacaktır.

- Ayrıca mevzuatta köyler için özel bir kanun bulunduğu halde mahalleler için böyle bir kanun bulunmamakta bu da birçok sorunu örneğin, muhtarlıkların kimle ve nasıl muhatap olacağ 1 karmaşıklığını ortaya çıkarmaktadır.

- Köylere hizmet götürme birlikleri gibi köylüye hizmet üreten birimlerin bu yeni kanunla atıl hale gelmiş olması hizmet maliyetlerinin artmasına sebebiyet verecektir.

- Ayrıca çalışmayla doğrudan ilgisi olması bakımından köy muhtarlıkları bu durumdan etkilenen en önemli organ olmuş, köy muhtarlı̆̆ının mahalle muhtarlığına dönüşmesiyle yetki ve sorumlulukları değişmiştir. Tüzel kişiliğini kaybetmesiyle yetki ve sorumlulukları büyük ölçüde zayıflamıştır.

6360 sayılı kanunla birlikte köylerin ve köy muhtarlıklarının idari yapılarında büyük değişimlerin yaşandığ 1 görülmektedir. Ancak Türkiye'de gerçekleşen bu reform çalışması bir kenara bırakıldığında günümüzde zaten köylerin mevcut durumu ve yerel yönetim sistemi içerisindeki yeri uzun süredir sorgulanmaktaydı. Köylerin 1982 anayasasının 127. maddesi kapsamında bir yerel yönetim birimi olduğu şüphesizdir. Fakat küreselleşmeyle birlikte ve çağın gereklerine uyum sağlaması noktasında sahip olduğu pozisyonu uygulamaya geçirdiğini ve gereklerini yaptığını söylemek çok güçtür. Günümüzde yaşadığı mali kaynak yetersizliği, nitelikli personel sorunu buna sebebiyet vermektedir. Ayrıca bir yerel yönetim birimi olan köyler, köy halkının ihtiyaçlarına cevap veremediği için sürekli olarak da merkezi yönetimin yardımına ihtiyaç duymakta bu durumda merkezi 
yönetimin köyler üzerinde müdahalesini gerektirmektedir (Şengül, 2016:147). Köy kanununda belirtilen çoğu görevlerinde merkezi yönetim tarafından yerine getirildiği görülmektedir. Yine Köy Kanunu günün koşullarına cevap verememesi, Türkiye'de köy yönetimlerine yönelik yeni bir reform çalışmasını gerekli ve zorunlu kılmıştır.

Tüm bunların karşısında mahalle yönetiminin anayasanın 127. maddesinde sözü edilen yerel yönetim birimlerinden biri olarak sayılmamış olması, yasa ile kurulmamaları, kamu tüzel kişiliklerinin olmayışı, kendilerine özgü bütçe ve personelinin bulunmayışı nedeniyle bir yerel yönetim birimi değildirler. Mahalle muhtarlığ kurumunu düzenleyen 1944 tarihli 4541 say1lı yasa gerekçesinde mahalle yönetimi, belde hizmetlerinin görülmesinde idareye yardımc1 bir kuruluş olarak görülmüştür. Oysa köy yönetimleri anayasanın 127. maddesine göre kamu tüzel kişiliğine sahip bir yerel yönetim birimi olmakta ve kiralama, satış, vergi toplama, mahkemede temsil gibi pek çok yetkisi bulunmaktadır. Köy yönetimlerinin organı olan muhtar ise köy yönetimlerinde tüzel kişiliğin temsilcisi ve tüm bu yetkileri kullanan önemli bir organ olmaktadır. Tüm bu anlatılanlardan hareketle Türkiye'de mahalle yönetiminin güçlü bir konumda olmadığ 1 ve merkezi yönetim ile yerel yönetimler arasında aracı bir kurum olmaktan öteye gidemediği çıkarımı yapılabilmektedir (Çelik ve Altıparmak, 2013:149).

Bunlara ek olarak mahalle yönetimine yönelik kanunun da 1944 yılında oluşturulması, günümüz koşullarına cevap verememesine ve mahallenin idari yapılanmada yerinin net olmayışı mahalle yönetiminin de pek çok sorunlar yaşadığının göstergesi olmaktadır. Bunlara ek olarak 6360 sayılı yasayla 16.082 köyün de tüm yetkilerini kaybederek mahalleye dönüşmesi, Türkiye'de mahallelere yönelik yeni bir reform çalışmasını da gerekli ve zorunlu kılmıştır. Ayrıca yasa ile ilgili genel anlamda yukarıda değinilen durumların faklı coğrafyalarda farklı şekillerde de ortaya çıkacağı öngörülmektedir. Bu bağlamda çalışmanın sonraki bölümünde Türkiye'de farklı yedi bölgede ve çalışmayı daha da desteklemesi amacıyla belediye yönetiminde farklı siyasi partilerin bulunduğu illerde yapılan bir alan çalışması yer almaktadır.

\section{MUHTARLARIN 6360 SAYILI YASA İLE BİRLIKTE YENI SÜRECE BAKIŞ AÇILARINI ORTAYA KOYAN BİR ALAN ARAŞTIRMASI}

Çalışmanın bu bölümünde Türkiye'de Büyükşehir olan 8 ilde (Kayseri, Erzurum, Samsun, Mardin, Tekirdağ, İzmir, Adana ve Kahramanmaraş) eski köy/yeni mahalle muhtarlarına ${ }^{1}$ uygulanmış olan anketin analizleri ve ortaya çıkan sonuçlar kapsamında yapılan yorumlar yer almaktadır.

\subsection{Araştırmanın Yöntemi, Evren ve Örneklemi}

Çalışmada araştırma yöntemlerinden biri olan "nicel araştırma" tekniğinden yararlanılmıştır. Literatür taraması sonucunda elde edilen bilgiler ve değerlendirmeler 1 şı̆̆ında çalışma alanı hakkında bilgiler verildikten sonra, çalışmanın Türkiye'ye genellenebilmesi için farklı bölgelerden seçilen Büyükşehir Belediyesi niteliğinde ve farklı siyasi partilerin yer aldığı 8 ilde (Kayseri, Erzurum, Samsun, Mardin, Tekirdağ, İzmir, Adana ve Kahramanmaraş) tümevarım yöntemi ile oluşturulan ve nicel araştırma tekniklerinden biri olan anket yöntemine başvurulmuştur. 6360 sayılı yasa sonrasında köylerin mahalle statüsüne dönüşmesi neticesinde bu dönüşümden etkilenen muhtarlara bu duruma bakış açılarını ortaya koyan/yaklaşımlarını ölçen sorular sorulmuştur.

Araştırma amacına uygun olarak hazırlanan anket soruları, araştırmacı tarafindan ilgililere dağıtılarak doldurulmuştur. Büyükşehir Belediyesine sahip ve farklı siyasi partilerin yer aldığ 8 ilde (Kayseri, Erzurum, Samsun, Mardin, Tekirdağ, İzmir, Adana ve Kahramanmaraş) yer alan 4688 muhtardan 340 muhtara ulaşılarak anketlerin doldurulması sağlanmış ve sonra SPSS ortamında veriler girilerek, soruların niteliğine göre çeşitli analizler uygulanmış ve sonuçları yorumlanmıştır. Aşağıdaki tabloda da evren ve örneklem detaylı gösterilmektedir.

1 Eski köy/yeni mahalle muhtarları, önceden köy muhtarı iken 6360 sayılı yasa sonrası köyün mahalleye dönüşmesiyle mahalle muhtarı olarak görev yapan kişiyi işaret etmektedir. 
Tablo 1. Evren ve Örneklem ${ }^{2}$

\begin{tabular}{|c|c|c|c|c|}
\hline ÍLLER & PARTILER & BÖLGELER & $\begin{array}{c}\text { ESKİ KÖY/ YENİ } \\
\text { MAHALLE MUHTARLARI }\end{array}$ & ULAŞILAN MUHTAR \\
\hline KAYSERİ & AK Parti & İç Anadolu Bölgesi & 397 Muhtar & 30 Muhtar \\
\hline ERZURUM & AK Parti & Doğu Anadolu Bölgesi & 965 Muhtar & 69 Muhtar \\
\hline SAMSUN & AK Parti & Karadeniz Bölgesi & 943 Muhtar & 68 Muhtar \\
\hline MARDIN & HDP & $\begin{array}{c}\text { Güneydoğu Anadolu } \\
\text { Röloesi }\end{array}$ & 607 Muhtar & 30 Muhtar \\
\hline TEKİRDAĞ & CHP & Marmara Bölgesi & 257 Muhtar & 20 Muhtar \\
\hline İZMİR & CHP & Ege Bölgesi & 595 Muhtar & 49 Muhtar \\
\hline ADANA & MHP & Akdeniz Bölgesi & 468 Muhtar & 34 Muhtar \\
\hline \multirow[t]{2}{*}{ K. MARAŞ } & AK Parti & Akdeniz Bölgesi & 474 Muhtar & 40 Muhtar \\
\hline & \multicolumn{2}{|c|}{ TOPLAM (8 İLDE) } & 4.685 Kìşi & 340 Kİşì \\
\hline
\end{tabular}

\subsection{Bulgular}

\subsubsection{Eski Köy/Yeni Mahalle Muhtarlarının Demografik Özelliklere Göre Dağılımı}

Bu bölümde 8 ilde çalışmaya katılan mahalle muhtarlarının cinsiyet, yaş, eğitim, meslek ve doğum yerleri gibi demografik özelliklerine göre frekans dağılımları verilmiştir.

Tablo 2. Cinsiyete Göre Dağılım

\begin{tabular}{ccc}
\hline Cinsiyet & Frekans & Yüzde \\
\hline Kadın & 0 & 0 \\
\hline Erkek & 340 & 100,0 \\
\hline Toplam & 340 & 100,0 \\
\hline
\end{tabular}

Tablo 2.'de görüldüğü üzere ankete katılan 340eski köy/yeni mahalle muhtarının\%100'ünün de erkek muhtar olduğu görülmektedir. Türkiye'de günümüzde toplamda 53 bin civarında muhtar bulunmaktadır. 2014 yerel seçimlerinden sonra, Türkiye'de 623 mahalle ve 51 köy olmak üzere toplam 674 kadın muhtar görev yapmaktadır. Bu doğrultuda erkek egemen bir muhtarlık yapılanması olduğu söylenebilir. Çalışmanın yapıldığı 8 il de ise 134 kadın muhtar bulunmakta olup anketin yapılması noktasında kadın muhtarlarla irtibata geçilememiştir. Ayrıca irtibata geçilen ve bulundukları mahallede anket yapılan eski köy/yeni mahallenin erkek muhtarlarına, 6360 sayılı yasa sonrası kendileri gibi bu değişiklikten etkilenen kadın muhtarların olup olmadığı da sorulmuş ancak bulundukları yerde böyle bir değişiklik yaşayan kadın muhtarların olmadığını dile getirmişlerdir.

Tablo 3. Doğum Yerine Göre Dağılım

Tablo 4. Görev Yapılan İle Göre Dağılım

\begin{tabular}{llllcc}
\hline Şehir & Frekans & Yüzde & Şehir & Frekans & Yüzde \\
\hline İzmir & 49 & 14,4 & İzmir & 49 & 14,4 \\
Samsun & 68 & 20 & Samsun & 68 & 20 \\
Erzurum & 69 & 20,5 & Erzurum & 69 & 20,5 \\
Tekirdağ & 20 & 5,8 & Tekirdağ & 20 & 5,8 \\
Adana & 34 & 10 & Adana & 34 & 10 \\
Kayseri & 30 & 8,8 & Kayseri & 30 & 8,8 \\
Mardin & 30 & 8,8 & Mardin & 30 & 8,8 \\
Kahramanmaraş & 40 & 11,7 & Kahramanmaraş & 40 & 11,7 \\
\hline Toplam & 340 & 100,0 & Toplam & 340 & 100,0 \\
\hline
\end{tabular}

2 Çalışma 31 Mart 2019 yerel seçimlerinden önce yapıldığı için evrende ve örneklemde yer alan illerde büyükşsehir yönetiminde yer alan siyasi partiler o dönemde mevcut olanları göstermektedir. 
Tablo 3.'de görüldüğü üzere ankete katılan 340 muhtarın doğum yerlerine göre dağılımları incelendiğinde muhtarların, \%14,4'ünün İzmir, \%20'sinin Samsun, \%20, 5'inin Erzurum, \%5,8'inin Tekirdağ, \%10'unun Adana, \%8,8'inin Kayseri, \%8,8'inin Mardin ve \%11,7'sinin de Kahramanmaraş'ta muhtarlık görevini sürdüğü tespit edilmiştir.

Tablo 4.'e göre ankete katılan 340 muhtarların görev yaptıkları illere göre dağılımları verilmiştir. Ankete katılan muhtarların görev yaptıkları illere göre dağılımları incelendiğinde, \%14,4'ünün İzmir, \%20'sinin Samsun, \%20, 5'inin Erzurum, \%5,8'inin Tekirdağ, \%10'unun Adana, \%8,8'inin Kayseri, \%8,8'inin Mardin ve \%11,7'sinin de Kahramanmaraş'ta muhtarlık görevini sürdüğü tespit edilmiştir. Görev yapılan illere ve Tablo 3.'e de bakıldığında ankete katılan muhtarın hepsinin kendi memleketlerinde görev yaptıkları söylenebilir.

Tablo 5. Yaşa Göre Dağılım

\begin{tabular}{ccc}
\hline Yaş & Frekans & Yüzde \\
\hline $18-25$ & 1 & 0,3 \\
$26-33$ & 1 & 0,3 \\
$34-41$ & 44 & 12,9 \\
$42-49$ & 125 & 36,8 \\
$\underline{50 \text { ve }}$ & $\underline{169}$ & $\underline{49,7}$ \\
$\underline{\text { Üzeri }}$ & $\mathbf{3 4 0}$ & 100,0 \\
\hline
\end{tabular}

Tablo 6. Eğitim Durumuna Göre Dağılım

\begin{tabular}{ccc}
\hline $\begin{array}{c}\text { Ĕğitim } \\
\text { Durumu }\end{array}$ & Frekans & Yüzde \\
\hline İlköğretim & 280 & 82,4 \\
Lise ve dengi & 55 & $\begin{array}{c}16,2 \\
1,4\end{array}$ \\
Diğer & 5 & 100,0 \\
\hline Toplam & 340 & \\
\hline
\end{tabular}

Ankete katılan 340 muhtarın yaşlarına göre dağılımları tablo 5'de gösterilmektedir. Ankete katılanların yaşa göre dağılımları incelendiğinde \%0,3'ü 18-25 yaş aralığında, \%0,3'ü 26-33 yaş aralığında, \%12,9'u 34-41 yaş aralığında, \%36,8'i 42-49 yaş aralığında ve \%49,7'si 50 yaş ve üzeri olduğu görülmektedir. Buradan hareketle ankete katılan eski köy/yeni mahallelerde her 4 muhtardan 3'ünün 40 ve üzeri yaş arasında olduğu çıkarımı yapılabilir.

Yukarıdaki Tablo 6' da ise ankete katılan muhtarların eğitim durumlarına göre dağılımları yer almaktadır. Ankete katılanlar eğitim durumuna göre incelendiğinde, \%82,4'ünün ilköğretim, \%16,2'sinin lise ve dengi ve \%1,4'ünün de diğer olduğu tespit edilmiştir. Bu kapsamda eski köy/yeni mahalle muhtarlarının eğitim düzeyleri değerlendirildiğinde büyük bir çoğunluğunun ilköğretim mezunu olduğu görülmektedir. Muhtarların eğitim düzeylerinin günümüz şartlarında iyi bir seviyede olmadığı saptanmıştır. Bu noktada muhtar olabilmek için belirli bir eğitim düzeyi şartının getirilmesi gerektiği düşünülmektedir.

Eski köy/yeni mahalle muhtarları mesleklerine göre incelendiğinde, \%8,8'inin esnaf, \%55,9'unun çiftçi, $\% 15,0$ '1nın serbest meslek, \%16,2'sinin emekli ve \%4,1'inin diğer meslek gruplarından olduğu görülmektedir. Genel anlamda bakıldığı zaman ankete katılanların çeşitli meslek kesimlerinden oluştuğu söylenebilmektedir. Yine ankete katılan 340 muhtarın medeni durumları incelendiğinde,\%93,5'inin evli, \%6,5'inin bekâr olduğu görülmektedir.

Tablo 7. Yürütülen Muhtarlık Türüne Göre Dağılım

\begin{tabular}{ccc}
\hline Türü & Frekans & Yüzde \\
\hline Mahalle muhtarlığı & 2 & -- \\
Köyden mahalleye dönüşen Mahalle Muhtarlığı (Eski Köy muhtarı) & 340 & 100,0 \\
\hline Toplam & 340 & 100,0 \\
\hline
\end{tabular}

Ankete katılanların Tablo 7'ye göre yürüttükleri muhtarlık türü incelendiğinde, \%0,6'sının mahalle muhtarlığ 1 , \%99,4'ünün ise 6360 sayılı yasa sonrasında büyükşehirlerde mevcut olan köylerin mahalleye dönüşmesiyle ortaya çıkan eski köy/ yeni mahalle muhtarı yani eski köy muhtarı olduğu görülmektedir. Çalışmada da sadece amacıyla uygun düşmesi açısından eski köy/yeni mahalle muhtarının verdiği cevaplar dikkate alınmıştır. 
$\mathrm{Bu}$ durum çalışmanın amacına da uygun düşmektedir. Çünkü çalışmanın amacı; eski köy/ yeni mahalle muhtarlarının, 6360 sayılı yasanın getirdiği düzenlemelerden olan köylerde ve mahallelerde yaşanan değişim ve dönüşümü nasıl algıladıklarını/yorumladıklarını ortaya koymaktır.

\subsubsection{Eski Köy/Yeni Mahalle Muhtarlarının 6360 Sayılı Yasayı Nasıl Algıladıklarına/Yorumladıklarına Göre Dağılım}

Bu bölümde 6360 sayılı yasa ile birlikte gelen düzenlemelerden ankete katılan muhtarın ne kadarının farkında olup olmadığını ortaya koymak ve yasayla birlikte köylerin mahalleye dönüşümünün muhtarlar tarafından nasıl algılandığını/karşılandığını ölçmek amaçlanmıştır.

Tablo 8. 6360 Sayılı Yasanın Getirdiği Düzenlemeleri Gösteren Dağılım

\begin{tabular}{cccc}
\hline $\begin{array}{c}\text { 6360 Sayılı Yasanın } \\
\text { Getirdiği Düzenlemeleri }\end{array}$ & Frekans & Frekans & Yüzde \\
\hline Büyükşehir sayısı arttı & Evet & 97 & 28,5 \\
& Hayır & 243 & 71,5 \\
Büyükşehirlerde ilçe sayısı arttı & Evet & 169 & 49,7 \\
& Hayır & 171 & 50,3 \\
İı̈ Özel İdareleri kaldırıldı & Evet & 180 & 52,9 \\
& Hayır & 160 & 47,1 \\
Köyler kaldırıldı & Evet & 233 & 68,5 \\
& Hayır & 107 & 31,5 \\
Büyükşehir hizmet sınırları genişletildi & Evet & 159 & 46,8 \\
& Hayır & 181 & 53,2 \\
Değişen bir şey olmadı & Evet & 8 & 2,4 \\
& Hayır & 332 & 97,6 \\
Sadece büyükşehirlerin sayısında bir artış oldu & Evet & 6 & 1,8 \\
& Hayır & 334 & 98,2 \\
\hline Büyükşehirlerde il özel idareleri ve köyler varlıklarını devam ettiriyorlar & Evet & 3 & 0,9 \\
\hline Toplam & Hayır & 337 & 99,1 \\
\hline
\end{tabular}

Tablo 8'de görüldüğü üzere ankete katılan 340 muhtara, “Aşağıdakilerden hangisi/hangileri 6360 sayıl yasanın getirdiği düzenlemelerdendir?”, sorusu sorulmuştur. Katılımcıların bu soruya cevapları şu şekilde olmuştur; büyük çoğunluğu, \%68,5'i "Köyler kaldırıldı" ifadesini işaretlemiştir. Yine büyük bir çoğunluğu \%52,9'u İl Özel İdareleri kaldırıldığı ve \%49,7’si Büyükşehirlerde ilçe sayısı arttığı yönünde yanıt vermiştir.

Verilen bu cevaplara bakıldığında muhtarların yasanın kendilerini ilgilendiren ve getirdiği büyük düzenlemelerden haberdar oldukları görülmektedir. Ancak köylerin kaldırılmadığını düşünen \%31,5'lik bir oran da dikkatleri çekmektedir. Bu konuda şöyle bir çıkarıma gidilebilir; 6360 sayılı Yasanın genel hatlarıyla muhtarlar tarafından bilinmesi fakat Türkiye geneli düşünüldügünde köylerin tamamının kapatılmadığ da göz önünde bulundurulduğunda muhtarların bu noktada bir kafa karışıklığı içerisinde oldukları ve ayrıca yasayı da ince ayrıntılarıyla bilmedikleri görülmüş sadece yaşadıkları durumlarla irtibatlı soruları bildikleri ortaya çıkmıştır.

Ayrıca katılımcıların \%25,5’i bu soruya "Büyükşehir sayısı arttı", \%46,8'i "Büyükşehir hizmet sınırları genişletildi”, \%2,4’ü "Değişen bir şey olmadı", \%1,8'i "Sadece büyükşehirlerin sayısında bir artış oldu" ve \%0,9'u ise "Büyükşehirlerde il özel idareleri ve köyler varlıklarını devam ettiriyorlar" ifadelerine "evet" yanıtını verdiği görülmektedir. 
Tablo 9. 6360 Sayılı Yasa Sonrasında Mevcut Bir Değişikliği Gösteren Dağılım

\begin{tabular}{ccc}
\hline $\begin{array}{c}\text { 6360 Sayılı Yasa } \\
\text { Sonrasında Mevcut }\end{array}$ & Frekans & Yüzde \\
\hline Evet, oldu & 62 & 18,2 \\
Hayır, olmadi & 216 & 63,5 \\
Kismen oldu & 47 & 13,8 \\
Fikrim yok & 15 & 4,4 \\
\hline Toplam & 340 & 100,0
\end{tabular}

Tablo 10. 6360 Sayılı Yasanın Hizmetlere Yönelik Etkisi

\begin{tabular}{ccc}
\hline Hizmetlerde Değişiklik Olup Olmadığı & Frekans & Yüzde \\
\hline Evet, iyi oldu & 77 & 22,6 \\
Kısmen iyi oldu & 109 & 32,1 \\
Hayır, değişiklik olmadı & 58 & 17,1 \\
Kötü oldu & 83 & 24,4 \\
Fikrim yok & 13 & 3,8 \\
\hline Toplam & 340 & 100,0 \\
\hline
\end{tabular}

Ankete katılan 340 muhtarın Tablo 9'da da görüldügü üzere "6360 sayıl yasa sonrasında mevcut durumunuzda bir değişiklik oldu mu?" sorusuna verdikleri cevaplara bakıldığında \%18,2'si "evet oldu" (belediyeden hizmet almaya başladık, şehirlere olan göçlerde artışlar yaşanmaya başladı çünkü vergiler geldi) cevabını vermişler ve gerekçelerine bakıldığında bu muhtarların kentsel alana yakın yerler olduğu saptanmıştır. \%63,5 büyük bir çoğunluk da "hayır olmadı" cevabını vermiş, hizmet noktasında değişen bir durum görmedikleri bunun da kırsal alanda olmalarından kaynaklı olduğu görülmüştür. Yine katılımcıların \%13,8'i "kısmen oldu" ve \%4,4'ü "fikrim yok" yanıtını vermiş olduğu görülmektedir.

Tablo 10'da görüldüğü üzere ankete katılan 340 muhtara "Sizce 6360 sayılı Yasayla, hizmetlere yönelik taleplerinizin karşıllı bulmasında herhangi bir değişiklik oldu mu?" sorusu sorulmuştur ve katılımcıların bu soruya cevapları şu şekilde olmuştur; \%22,6's1 "evet iyi oldu" cevabını verirken \%24,4'ü bu durumun "kötü olduğunu" belirtmiştir. Bu cevabı vermelerinin nedeni ise 6360 sayılı yasa sonrası mahalle olmalarından sonra istedikleri hizmeti alamamaları, belediyelerde işlemlerin çok uzun sürmesi ve sonuç alınamaması olmasıdır. Ayrıca köy muhtarıyken gördükleri ilgi ve alakayı mahalle muhtarıyken görememelerini de eklemişlerdir. Çünkü köy muhtarıyken bir yerel yönetim organı olarak sahip oldukları tüzel kişilik temsilcisi olma durumu mahalle muhtarı olunca ortadan kalkış bu durum kurumlarda olan saygınlıklarının da zedelenmesini sağlamıştır. Katılımcılar ankete bunu aynı şekilde belirtmişlerdir. Ankete katılan 340 muhtarın \%32,1'lik gibi büyük bir kısmı "kısmen iyi oldu" cevabını vermiştir. Bu cevabı verenler ise belediyenin hizmet sunumlarında il özel idaresinden daha iyi olduğunu belirtmiş ve bazı muhtarlar da sorumluluğun mahalle muhtarı olunca azaldığını ve bu durumun da eskiye göre daha iyi olduğunu savunmuştur. Yine kente yaklaştıkça memnuniyet seviyesinin artığı bu soruda da ortaya çıkmıştır. Katılımcıların \%17,1'i ise bu soruya "hayır değişiklik olmadı" cevabını verirken \%3,8'i “fikrim yok" cevabını vermiştir.

Tablo 11. 6360 Sayılı Yasa Sonrasında Mahallenin İhtiyaçları İçin Talepte Bulunulan İdari Birimler

\begin{tabular}{ccc}
\hline $\begin{array}{c}\text { Talepte Bulunulan } \\
\text { Birim }\end{array}$ & Frekans & Yüzde \\
\hline Belediyeden & 248 & 72,9 \\
Valilikten & 2 & 0,6 \\
Kaymakamlıktan & 10 & 2,9 \\
Hepsinden & 60 & 17,6 \\
Hiçbirinden & 3 & 0,9 \\
Fikrim yok & 17 & 5,0 \\
\hline Toplam & 340 & 100,0
\end{tabular}

Tablo 12. Yeni Mahalleye Yönelik Verilen Eski Köyün/Yeni Hizmetlerin Etkin ve Verimli Bir Şekilde Sunulup Sunulmaması

\begin{tabular}{ccc}
\hline $\begin{array}{c}\text { Yeni Mahalleye Yönelik Verilen } \\
\text { Hizmetlerin Etkin ve Verimliliği }\end{array}$ & Frekans & Yüzde \\
\hline Evet, hizmet sunumları etkin ve verimli & 135 & 39,7 \\
Hayır, hizmet sunumları etkin ve verimli değil & 78 & 22,9 \\
Kismen hizmet sunumları etkin ve verimli & 119 & 35,0 \\
Fikrim yok & 8 & 2,4 \\
\hline Toplam & 340 & 100,0 \\
\hline
\end{tabular}

Tablo 11'de görüldüğü üzere ankete katılan 340 muhtara "6360 sayılı Yasa sonrasında eski köyün/yeni mahallenin ihtiyaçları için hangi birimden talepte bulunuyorsunuz?” sorusu sorulmuştur. Muhtarların \%72,9'u "belediyeden" talepte bulunduklarını belirtmekte ve bu durum literatürü de desteklemektedir. Çünkü 6360 sayılı Yasa sonrası mahalleye dönüşen köyler belediye sınırları içerisinde sayıldığı için tüm hizmetler belediye tarafından yerine getirilecektir. Buna ek olarak yasa ile il özel idareleri kaldırıldığı için kentsel alana dâhil edilen eski köy/yeni mahalle muhtarlarının kaymakamlıktan ya da il özel idarelerinden hizmet talep edemez 
duruma gelmiştir. Yine bu soruya katılımcıların \%0,6's1 "valilikten", \%2,9'u "kaymakamlıktan" cevabını verirken muhtarlar içerisinde hala kafasının karışık olduğu ve hizmeti kimden talep edeceklerini bilmeyenler de bulunmaktadır. Ancak eski köy7yeni mahalle muhtarlarının \%17,6's1 "hepsinden" şıkkını işaretlemesi dikkat çekmektedir. Burada şöyle bir yoruma gitmek yerinde görülmektedir. Bu şıkkı işaretleyen mahalle muhtarlığının temsilcilik/aracılık rolünü kullanarak hem merkezden hem de yerelden talepte bulunma hakkının olduğunu düşünmesidir ki bu doğru bir karardır literatürle de uyuşmaktadır. Katılımcıların \%0,9'u ise "hiçbirinden" talepte bulunmadığını belirtirken talepte bulunmayı bilmeyen muhtarlarının olduğu da bu şıkta ortaya çıkmıştır. Yine katılımcıların \%5,0’ı ise bu konuda "fikrinin olmadığı" yönünde cevap vermiştir.

Ankete katılan 340 muhtarın Tablo 12'de de görüldüğü üzere, "Yeni mahallenin ihtiyaçları için talepte bulunduğunuzda hizmetlerin etkin ve verimli sunulduğunu düşünüyor musunuz?" sorusuna cevap verdikleri görülmektedir. Eski köy/yeni mahalle muhtarını \%39,7’lik kısmı bu soruya "evet, hizmet sunumları etkin ve verimli sunulduğunu" belirtmiş ve bu cevap bir önceki soruyu da desteklemiştir. Kentsel alanda yer alan ya da kentsel alana yakın yerlerdeki muhtarlar böyle düşünmekte çünkü hizmet buralara gitmekte ve gerçekleşen hizmetlerin etkin ve verimli olduğu düşünülmektedir. Katılımcıların \%22,9'u "hayır, hizmet sunumları etkin ve verimli" değil şeklinde cevap verdikleri görülmüştür. Yine bu soruya katılımcıların \%35,0’1 "kısmen hizmet sunumları etkin ve verimli" olduğunu belirtmişlerdir. Bunun göstergesi olarak ise yollara asfalt döküldüğü fakat altyapı kontrol edilmeden, alt yapı sorunu çözülmeden bunun yapıldığını belirtilmiştir. Yani bir yerde hizmetin gerçekleştiği fakat bunun etkin ve verimli olmadığı dile getirilmiştir. Bu düşünceye sahip olanlar ise kentsel alana uzak olan kırsal yerdeki muhtarlar olduğu aşikârdır. Çünkü kentsel alanda belediye aktif olarak hizmeti gerçekleştirdiği ancak kırsal ve uzak yerlere belediyenin gelmesinin geciktiği ve sunulan hizmetin de yaşanan gecikmeler ya da beklenilen hizmetle uyuşmadığ 1 görülmüştür. Katılımcıların \%2,4'ü ise bu konuda bir "fikrinin olmadığını" söylemiştir.

Tablo 13. Köy Muhtarlığından Mahalle

Muhtarlığına Dönüşülmesi Dolayısıyla

Gerçekleştirilecek Kamu Hizmetlerindeki

Değişiklik/Değişim Durumu

\begin{tabular}{ccc}
\hline Hizmetler İçeriklerinde Değişiklik & Frekans & Yüzde \\
\hline Evet, hizmetler arttı & 42 & 12,4 \\
Kısmen arttı & 15 & 4,4 \\
Hayır, bir değişiklik olmadı & 69 & 20,3 \\
Hizmet içeriğinde azalma oldu & 188 & 55,3 \\
Fikrim yok & 26 & 7,6 \\
\hline Toplam & 340 & 100,0 \\
\hline
\end{tabular}

Tablo 14. Kirsal Alan Yoğunluğu Fazla Olan Yerlerde Mahalle Muhtarlarının Kimliğini Güçlendirmeye Yönelik Düzenleme Yapılması İhtiyacı Düşüncesi

\begin{tabular}{ccc}
\hline Düzenlemelerin Gerekip Gerekmediği & Frekans & Yüzde \\
\hline Evet, yapılmalı & 239 & 70,3 \\
Hayır, gerek yok & 71 & 20,9 \\
Fikrim yok & 30 & 8,8 \\
\hline Toplam & 340 & 100,0 \\
\hline
\end{tabular}

Tablo 13'de görüldüğü üzere ankete katılan 340 muhtara "Köy muhtarı iken mahalle muhtarı olmanızdan dolayl yerine getirmek durumunda kaldığınız hizmet içeriklerinde bir değişiklik oldu mu?", sorusu sorulmuştur ve katılımcıların bu soruya cevapları şu şekilde olmuştur; \%12,4'ü "evet hizmetler arttı" ifadesini işaretlemiştir. Ancak katılımcıların bu konuda bazı şikâyetlerinin de olduğu gözlemlenmiştir. Mesela katılımcılar bu şıkkı belirtirken hizmet alabilmek için ise belediyelerde koşturmak zorunda kaldıklarını, çok süre beklediklerini ve bu durumun zaman kaybına neden olduğunu belirtmişlerdir. Çünkü ilgili muhtarlıklar tüzel kişiliklerini kaybettiklerinden dolayı kendilerine dar bir çerçevede karar alma ve bu kararı uygulama imkânı yaratılmakta ve yine tüzel kişiliklerini kaybetmelerinden kaynaklanan sorunların başında mahallelerine hizmet yapma ve alma imkânları elinden alınmış olması gelmektedir. Katılımcıların \%4,4'ü "kısmen arttı", \%20,3'ü "hayır bir değişiklik olmadı" yönünde cevap verirken \%55,3'ü ise "hizmet içeriğinde azalmalar" olduğunu dile getirmiştir. Mesela bu kapsamda yükümlülüklerinin azaldığı ve mahalle muhtarı olunmasından dolayı itibar kaybı yaşadıkları muhtarlar tarafından belirtilmiştir. Burada da tüzel kişiliklerini kaybetmelerinden dolayı yaşanan sıkıntılar olduğu görülmektedir. Katılımcıların\% 7,6'sınınise bu konuda bir "fikrinin olmadığı" görülmektedir.

Ankete katılan 340 muhtarın Tablo 14'de de görüldüğü üzere “Özellikle krrsal alan yoğunluğu fazla olan büyükşehir belediyeleri düşünüldüğ̈̈nde, mahalle muhtarı kimliğini güçlendirmeye yönelik düzenlemeler yapılması gerekir mi?", sorusuna verdikleri cevaplara bakıldığında \%70,3'ü "evet yapılmalı" cevabını vermiştir. Katılımcıların büyük bir çoğunluğu muhtarların yetkilerinin artırılması gerektiğini, şu durumda yetkilerinin olmadığını ve yetkisiz oldukları için ellerinin kollarının bağlı olduğunu belirtmektedirler. Ayrıca kente uzak oldukları gibi yetkilerinin de ellerinden alınması, kırsal alanda problemlerin yaşanması fakat yetkileri olmadığı için problemleri çözemedikleri görülmektedir. Ancak ankete katılanların \%20,9'u ise "hayır gerek yok" 
şeklindeki ifadeyi işaretlemiş ve sorumluluk almamanın, yetkisiz olmanın eskiye nispeten daha iyi olduğunu söylemişlerdir. Çünkü bu tarz düşünen muhtarların olduğu alanlara belediyeye gerekli hizmeti sunmaktadır. Yine ankete katılanların \%8,8'inin ise bu konuda bir “fikrinin olmadı̆̆ı" görülmektedir.

Tablo 15. 6360 Sayılı Yasayla Oluşan Eski Köy/Yeni Mahalleler İçin Mahalle Kanununun Revize Edilmesi Sorunların Çözümünde Katkı Sağlayıp Sağlamayacağını Gösteren Dağılım

\begin{tabular}{ccc}
\hline $\begin{array}{c}\text { Mahalle Kanununun Revize Edilmesi Sorunların } \\
\text { Çözümünde Katkı Sağlayıp Sağlamayacağı }\end{array}$ & Frekans & Yüzde \\
\hline Evet, sağlar & 148 & 43,5 \\
Hayır, gerek yok & 77 & 22,6 \\
Kısmen & 44 & 12,9 \\
Fikrim yok & 71 & 20,9 \\
\hline Toplam & 340 & 100,0
\end{tabular}

Tablo 15'de görüldüğü üzere ankete katılan 340 muhtara "6360 sayılı Yasayla oluşan eski köy/yeni mahalleler için Mahalle Kanununun revize edilmesi sorunların çözümünde katkı sağlar mı?” sorusu sorulmuştur. Ankete katılan katılımcıların \%43,5'i "evet sağlar" ifadesini işaretlerken özellikle de yeni yapılacak kanunun orman köylüsüne yönelik düzenlemeler içermesi gerektiğini vurgulamıştır. Çünkü katılımcılara göre 6360 sayılı Yasa sonrası orman köyleri katledilmektedir. Bundan dolayı yeni kanun bu durumu dikkate alarak orman köylüsünün sorununu çözmeye yönelik olmalıdır şeklinde ifadeler ankette yer almaktadır. Yine katılımcıların \%22,6's1 "hayır gerek yok" cevabını işaretlerken yeni kanun yapılsa bile sıkıntıları çözemeyeceği yönünde bir umutsuzluklarının olduğu görülmüştür. Çünkü katılımcılar 6360 sayılı yasanın da revize edilmesi gerektiği düşüncesindeler ve bunu ankete işlemişlerdir. Özellikle kırsal alanlarda yer alan mahallelere yönelik özel hükümlere ki bunlar arasında orman köyleri, hayvancılığın ve tarımın yoğun yapıldığı yerler gelmekte, yer verilmelidir. Ayrıca katılımcıların \%12,9'u bu soruya "kısmen" cevabını verirken \%20,9'luk gibi çoğunluğu da “fikrinin olmadığını" belirtmiştir.

Tablo 16. Köyün Mahalleye Dönüşmesi Eski Köylünün/Yeni Mahallelinin Hayatında En Çok Hangi Üç Alanda Etkili Olduğu Durumunu Gösteren Dağılım

\begin{tabular}{cccc}
\hline $\begin{array}{c}\text { Köyün Mahalleye Dönüşmesi Eski Köylünün/Yeni } \\
\text { Mahallelinin Hayatında En Çok Etkilediği Üç Alan }\end{array}$ & Frekans & Frekans & Yüzde \\
\hline Hiçbir değişim olmadı & Evet & 82 & 24,1 \\
& Hayır & 258 & 75,9 \\
Vergiler yükseldi & Evet & 122 & 35,9 \\
& Hayır & 218 & 64,1 \\
Yeni yük getirdi ve olumsuz etkilendik & Evet & 187 & 55,0 \\
& Hayır & 153 & 45,0 \\
Resmi işlemler kolaylaştı & Evet & 79 & 23,2 \\
& Hayır & 261 & 76,8 \\
& Evet & 131 & 38,5 \\
Tarım ve hayvancılık yapamaz olduk & Hayır & 209 & 61,5 \\
& Evet & 31 & 9,1 \\
Şehirli vatandaşlar olduk & Hayır & 309 & 90,9 \\
& Evet & 8 & 2,4 \\
Ekonomik gelişme sağlandı & Hayır & 332 & 97,6 \\
& Evet & 14 & 4,1 \\
Şehirli yaşam standardını yakaladık & Hayır & 326 & 95,9 \\
Diğer & & 9 & 2,6 \\
\hline Toplam & 340 & 100,0 \\
\hline
\end{tabular}

Tablo 16'da görüldüğü üzere ankete kat1lan 340 muhtara "Köyün mahalleye dönüşmesi eski köylünün/yeni mahallelinin hayatında en çok hangi üç alanda etkili oldu?", sorusu sorulmuştur ve katılımcıların \%55'i "Yeni yük getirdi ve olumsuz etkilendik" , \%38,5'i "Tarım ve hayvancılık yapamaz olduk" cevabını verirken \%35,9'u ise "Vergiler yükseldi" ifadesine işaretlemişlerdir. Görülen o ki ankete katılanların ilk üç şık olarak işaretledikleri 6360 sayılı yasa sonrası kendilerini olumsuz etkileyen düzenlemelerdir. Tabloya tersten bakıldığında ise dikkat çeken önemli şıklar olduğu da görülmektedir. Keza bu kapsamda öne çıkan ilk 3 şıka bakıldığında katılımcıların \%97,6'lık gibi büyük bir çoğunluğu "ekonomik gelişmenin sağlanmadığını" düşünmektedir. \%95,9 gibi önemli bir oranı "ş̧ehirli yaşam standardını yakalayamadıklarını” ve \%90,9'u gibi 
yine büyük bir çoğunluğu da "şehirli vatandaşlar olamadıklarını" belirtmişlerdir. Eski köyde yaşayan yeni mahalleli olarak hayatlarında bir değişim olmadığı, özellikle de kente uzak olan mahallelerde, düşünsel olarak kentle bütünleşilmediği ve kente ve kentli olmaya yabancı oldukları görülmektedir. $\mathrm{Bu}$ doğrultuda bu yeni mahallelere kentsel- sosyal imkânların acilen götürülmesi bir gereklilik olmuştur.

Tablo 17. Köyünüzün Mahalleye Dönüşmesinden Dolayı Köylüler Kendilerini Kentte Yaşıyor Gibi Ortaya Koyan Dağılım

\begin{tabular}{ccc}
\hline Kentte Yaşıyor Gibi Hissetme & Frekans & Yüzde \\
\hline Evet & 10 & 2,9 \\
Hayır & 221 & 65,0 \\
Kısmen, & 81 & 23,8 \\
Fikrim yok & 28 & 8,2 \\
\hline Toplam & 340 & 100,0 \\
\hline
\end{tabular}

Tablo 17'de görüldüğü üzere ankete kat1lan 340 muhtara "Köyünüzün mahalleye dönüşmesinden dolayı köylüler kendilerini kentte yaşlyor gibi hissediyorlar mı?", sorusu sorulmuştur. Katılımcıların \%2,9'luk gibi çok az bir kısmı "evet" cevabını verirken, \%65,0’1 gibi büyük bir kısmı ise "hayır" cevabını vermiştir. Katılımcılar hayır cevabını verirken bunun gerekçesi olarak ise kentte ulaşımın olduğu kırsal alanda olmadığı, kırsal alanda kentli gibi hissetmenin mümkün olamayacağı keza halkın da böyle hissettiği ankete yansıtılmıştır. Ayrıca hala alt yapı sorunu yaşanılan bir yerde kentli nasıl olunabileceği de muhtarlar tarafından sorgulanmaktadır. Tablo 42'de verilen cevaplar da bu durumu desteklemekte ve şehirli yaşam standardının yakalanamadığ olmadıkları nerdeyse katılımcıların tamamı tarafından kabul edilmektedir. Yine ankete katılan katılımcıların $\% 23,8$ 'i bu soruya "kısmen" cevabını verirken ulaşım noktasında sıkıntıların biraz çözüldüğünü dile getirmiştir. $\% 8,2$ 'si ise bu soruya "fikrim yok" yanıtını vermiştir.

Ankete katılan 340 muhtarın Tablo 18'de de görüldüğü üzere "Sizce köyleriniz mahalleye dönüşmeli miydi?", sorusuna verdikleri cevaplara bakıldığında \%58,2'lik gibi büyük bir kısmı "hayır" cevabını vermiştir. Bu oranın "köyün mahalleye dönüşmesinden memnun olmayanların" oranına da yakın olması ayrıca dikkat çekmektedir. Burada verilen cevapların birbiriyle örtüştügünü göstermektedir. Yine muhtarlar "hayır" cevabını verirken bunun gerekçesi olarak eski düzenin daha iyi olduğu, köye ait arsaların, karar defterlerinin olduğu ifade edilirken, tüzel kişiliklerinin kalkması, sorunların çözülmemesi ve ormanların katledilmesi gösterilmiştir. Ayrıca bazı muhtarlara göre mahalle olunduktan sonra belediyenin her işe karışır olması da sıkıntıları daha da artırdığı ifade edilmektedir. Çünkü 6360 sayılı yasadan önce eski köy/yeni mahalle muhtarlarının özerklikleri bulunmaktaydı ve kendi alanlarında yani yetki alanlarında tüzel kişiliklerini de kullanarak tek söz sahibiydiler fakat mahalle olduktan sonra tüzel kişilikleri ve özerklikleri ellerinden alınmış ve belediyeler yetki alanlarına girmiştir. Belediyelerin kendilerinin yetki alanlarına giriyor olması da muhtarlarının memnun olmadıkları durumlar arasındadır. Yine katılımcıların \%29,1'i bu soruya "evet" cevabını verirken \%12,6's1 ise "fikrim yok" cevabını vermiştir.

Tablo 19. 6360 Sayılı Yasa Sonrası Yaşanılan En Temel Sorun Gösteren Dağılım

\begin{tabular}{|c|c|c|c|}
\hline Yaşanılan Temel Sorun & & Frekans & Yüzde \\
\hline Köye/ mahalleye yönelikler talepleri kimden istenileceği & $\begin{array}{c}\text { Evet } \\
\text { Hayır }\end{array}$ & $\begin{array}{c}46 \\
294\end{array}$ & $\begin{array}{l}13,5 \\
86,5\end{array}$ \\
\hline Mevcut olan maddi kaynak gelirini kaybetmiş olmak & $\begin{array}{l}\text { Evet } \\
\text { Hayır }\end{array}$ & $\begin{array}{c}97 \\
243\end{array}$ & $\begin{array}{l}28,5 \\
71,5\end{array}$ \\
\hline Köy tüzel kişiliğinin sona ermesi & $\begin{array}{l}\text { Evet } \\
\text { Hayır }\end{array}$ & $\begin{array}{l}154 \\
186\end{array}$ & $\begin{array}{l}45,3 \\
54,7\end{array}$ \\
\hline Kamu kurumlarında istenilen saygınlığı görememek & $\begin{array}{l}\text { Evet } \\
\text { Hayır }\end{array}$ & $\begin{array}{c}48 \\
292\end{array}$ & $\begin{array}{l}14,1 \\
85,9\end{array}$ \\
\hline Köy/ mahalle için istenilen taleplerin çok gecikmeli olarak gelmesi & $\begin{array}{l}\text { Evet } \\
\text { Hayır }\end{array}$ & $\begin{array}{l}136 \\
204\end{array}$ & $\begin{array}{l}40,0 \\
60,0\end{array}$ \\
\hline Muhtarlık kurumunun etkisiz hale getirilmesi & $\begin{array}{l}\text { Evet } \\
\text { Hayır }\end{array}$ & $\begin{array}{l}110 \\
230\end{array}$ & $\begin{array}{l}32,4 \\
67,6\end{array}$ \\
\hline Belediye - Muhtarlık ilişkisinin olumsuz etkilenmesi & $\begin{array}{l}\text { Evet } \\
\text { Hayır }\end{array}$ & $\begin{array}{c}7 \\
333\end{array}$ & $\begin{array}{c}2,1 \\
97,9\end{array}$ \\
\hline Diğer & & 12 & 3,5 \\
\hline Toplam & & 340 & 100,0 \\
\hline
\end{tabular}


Ankete katılan 340 muhtarın Tablo 19'da da görüldüğü üzere "6360 sayılı Yasa sonrası yaşadığınız en temel sorun olarak aşağıdakilerden hangisini görüyorsunuz?”, sorusuna verdikleri cevaplara bakıldığında büyük bir çoğunluğunun şu üç şıta hemfikir olduğu görülmektedir. \%45,3’ü "Köy tüzel kişiliğinin sona ermesi”, - ki en çok muhtarların şikâyetçi olduğu durum- \%40,0'1 "Köy/ mahalle için istenilen taleplerin çok gecikmeli olarak gelmesi" ve \%32,4'ü "Muhtarlık kurumunun etkisiz hale getirilmesi" dir. Yine bu soruya verilen cevaplarda oranlara bakıldığında kentsel alana uzaklık yakınlık durumunun etkisinin olduğu öne çıkmakta ve önceki sorularla bu sorudaki oranların benzer olduğu saptanmaktadır. Yine verilen cevaplara bakıldığında \%28,5'i "Mevcut olan maddi kaynak gelirini kaybetmiş olmak",\%14,1'i "Kamu kurumlarında istenilen saygınlığ1 görememek", \%13,5'i "Köye/ mahalleye yönelikler talepleri kimden istenileceği", \%3,5'i "Diğer" ifadesini işaretlerken $\% 2,1$ 'i ise "Belediye - Muhtarlık ilişkisinin olumsuz etkilenmesi", seçeneğini işaretlediği görülmektedir.

Tablo 20. Muhtarlık Biriminin Günümüz Şartlarında Daha Da İyileşmesi İçin Neler Yapılabilir Önermesini Gösteren Dağılım

\begin{tabular}{|c|c|c|c|}
\hline Yaşanılan Temel Sorun & & Frekans & Yüzde \\
\hline Gerek yok, şu anki durum gayet iyi & $\begin{array}{l}\text { Evet } \\
\text { Hayır }\end{array}$ & $\begin{array}{c}69 \\
271\end{array}$ & $\begin{array}{l}20,3 \\
79,7\end{array}$ \\
\hline 6360 sayılı yasa öncesi durum devam etmeli & $\begin{array}{l}\text { Evet } \\
\text { Hayır }\end{array}$ & $\begin{array}{c}87 \\
253\end{array}$ & $\begin{array}{l}25,6 \\
74,4\end{array}$ \\
\hline Tek bir yapılanma içerisinde devam etmeli & $\begin{array}{l}\text { Evet } \\
\text { Hayır }\end{array}$ & $\begin{array}{c}19 \\
321\end{array}$ & $\begin{array}{c}5,6 \\
94,4\end{array}$ \\
\hline Köyler mahalle olmalı ancak köy yönetiminin hak ve sorumluluklarını da devralarak & $\begin{array}{l}\text { Evet } \\
\text { Hayır }\end{array}$ & $\begin{array}{c}71 \\
269\end{array}$ & $\begin{array}{l}20,9 \\
79,1\end{array}$ \\
\hline Yeni yasal düzenlemelere gidilmeli & $\begin{array}{l}\text { Evet } \\
\text { Hayır }\end{array}$ & $\begin{array}{c}67 \\
273\end{array}$ & $\begin{array}{l}19,7 \\
80,3\end{array}$ \\
\hline Kendine ait bütçesi olmalı & $\begin{array}{l}\text { Evet } \\
\text { Hayır }\end{array}$ & $\begin{array}{l}161 \\
179\end{array}$ & $\begin{array}{l}47,4 \\
52,6\end{array}$ \\
\hline Kendisi ile ilgili karaları serbest alıp verebilmeli & $\begin{array}{l}\text { Evet } \\
\text { Hayır }\end{array}$ & $\begin{array}{c}90 \\
250\end{array}$ & $\begin{array}{l}26,5 \\
73,5\end{array}$ \\
\hline Siyasilerin baskısından uzak olmalı & $\begin{array}{l}\text { Evet } \\
\text { Hayır }\end{array}$ & $\begin{array}{c}18 \\
322\end{array}$ & $\begin{array}{c}5,3 \\
94,7\end{array}$ \\
\hline Tüzel kişilik tanınmalı & $\begin{array}{l}\text { Evet } \\
\text { Hayır }\end{array}$ & $\begin{array}{l}137 \\
203\end{array}$ & $\begin{array}{l}40,3 \\
59,7\end{array}$ \\
\hline İdari yapıda yönetsel bir birim olarak varlık bulmalı & $\begin{array}{l}\text { Evet } \\
\text { Hayır }\end{array}$ & $\begin{array}{c}15 \\
325\end{array}$ & $\begin{array}{c}4,4 \\
95,6\end{array}$ \\
\hline Belediye - Muhtarlık diyalogunu artırılmalı & $\begin{array}{l}\text { Evet } \\
\text { Hayır }\end{array}$ & $\begin{array}{c}18 \\
322\end{array}$ & $\begin{array}{c}5,3 \\
94,7\end{array}$ \\
\hline Diğer & & 8 & 2,4 \\
\hline Toplam & & 340 & 100 \\
\hline
\end{tabular}

Ankete katılan 340 muhtarın Tablo 20'de de görüldüğü üzere, “Muhtarlık biriminin günümüz şartlarında daha da iyileşmesi için neler yapılabilir?", sorusuna verdikleri cevaplara bakıldığında \%47,4'ü "Kendine ait bütçesi olması gerektiği görüşünü savunmaktadır. \%40,3'lük gibi büyük bir kısmı "Tüzel kişilik tanınmalı" şeklinde ifadeye katılmışlardır. Yine \%26,5'i ise "Kendisi ile ilgili karaları serbest alıp verebilmeli", \%25,6's1 "6360 sayılı yasa öncesi durum devam etmeli" şıkkını işaretlemiştir. Muhtarların büyük çoğunluğunun işaretlediği bu şıklar göstermektedir ki eski köy/ yeni mahalle muhtarları köy muhtarıyken sahip oldukları yetkilere tekrar sahip olmak istemekte ve mahalle muhtarlığını yetkisi ve vasfi olmayan bir birim olarak görmektedir.

Katılımcılar tarafından verilen cevaplara bakıldığında \%20,3'ü bu soruya "Gerek yok, şu anki durum gayet iyi”" cevabını verirken \%25,6'sı "6360 sayılı yasa öncesi durum devam etmeli" şıkkını işaretlemeleri de dikkat çekmekte çünkü katılımcıların kentsel alana uzaklık ve yakınlık durumları da birbirine yakın olmaktadır. Böylece kentsel alana yakın olanlar "Gerek yok, şu anki durum gayet iyi”" cevabını verirken kırsal alana yakın olanlar ise "6360 sayılı yasa öncesi durum devam etmeli" cevabını verdiği görülmektedir. Katılımcılar tarafından verilen cevaplara bakıldığında, \%5,6's1 "Tek bir yapılanma içerisinde devam etmeli”, \%20,9'u "Köyler mahalle olmalı ancak köy yönetiminin hak ve sorumluluklarını da devralarak", \%19,7'si "Yeni yasal düzenlemelere gidilmeli", \%5,3'ü "Siyasilerin baskısından uzak olmalı", \%4,4'ü "İdari yapıda yönetsel bir birim olarak varlık bulmalı", \%5,3'ü "Belediye - Muhtarlık diyalogunu artırılmalı", \%2,4'ü ise "Diğer" seçeneğini işaretlediği görülmektedir. 


\section{SONUÇ VE DEĞERLENDİRME}

Türkiye'de 7 farklı bölgede bulunan 8 ilde ankete katılan 340 muhtarın ankette yer alan; Demografik özelliklerini ve 6360 sayılı Yasayı nasıl yorumladıklarını/algıladıklarını ölçen soru kategorilerine verdikleri cevaplara genel olarak bakıldığında çeşitli çıkarımlar yapmak mümkün olmaktadır. Ayrıca bu çıkarımlardan hareketle muhtarların 6360 sayılı Yasa sonrası oluşan ve 6360 sayılı Yasa öncesi de mevcut olan sorunlarına yönelik çeşitli öneriler de geliştirilmiştir. Bu kapsamda şunları söylemek mümkündür;

- Ankete katılan katılımcıların tamamı erkek muhtarlardan oluşmaktadır. Buradan hareketle Türkiye'de erkek egemen bir muhtarlık yapılanması olduğu söylenebilir. Çünkü Türkiye'de 53 bin civarında muhtar bulunmakta ve bunun sadece 674'ünün kadın muhtar olduğu 2014 yerel seçimlerinden sonra saptanmıştır. Çalışmanın yapıldığ 1 yerlerde ise anket uygulanan erkek muhtarlara kendileri gibi 6360 sayılı yasadan etkilenen kadın muhtarların olup olmadığı sorulmuş ancak böyle bir değişiklik yaşayan kadın muhtarların olmadığı dile getirilmiştir. Bu noktada yasal mevzuatta değişikliğe gidilmesi önerilebilmektedir. Ayrıca muhtarlık yapılanmasında kadın muhtarların da sayılarının artırılması sağlanmalıdır.

- Katılımcıların doğum yerlerine bakıldığında hepsinin kendi doğdukları yerlerde muhtarlık görevini yerine getirdiği görülmektedir. $\mathrm{Bu}$ durum vatandaşın beklediği hizmete muhtar tarafından doğru karşl1ık verilmesini sağlamada önemli bir unsur olmaktadır.

- Ankete katılan muhtarların demografik özelliklerinden yaş dağılımları ve eğitim durumları da çalışma kapsamınca önemli görülmektedir. Çünkü eski köy/yeni mahallelerde her 4 muhtardan 3 'ünün 40 ve üzeri yaş arasında olduğu görülmüş ve Türkiye'de muhtarlık yapılanmasına orta yaş grubunun hâkim olduğu saptanmıştır. Bu noktada gençlerin bu tarz görevlerde yer almasını sağlayacak adımların atılması önemli görülmektedir. Muhtarların eğitim düzeylerine bakıldığında ise günümüz şartlarıyla çok da uyumlu olmayan bir gerçek ortaya çıkmıştır. Muhtarların neredeyse tamamının ilköğretim mezunu olduğu görülmüştür. Bu eğitim düzeyinin iyi bir seviyede olmadığı aşikârdır. Bu noktada muhtar olabilmek için modern dünyanın koşularına uygun bir eğitim şartının getirilmesi gerekli görülmektedir. Ayrıca çalışmanın amacına uygun olarak ve sürecin tahlil edilmesi noktasında da ankete katılan tüm katılımcıların eski köy/yeni mahalle muhtarı olması çalışma için büyük öneme sahiptir.

- Türkiye'de büyükşehir yönetimlerini ilgilendiren son yasa 6360 say1lı Yasa olup, bu yasa 2014 y1l1 itibariyle uygulanmaya başlanmıştır. Ankete katılan muhtarlara "6360 sayılı yasa hakkında bilgilerinin olup olmadığı" sorulmuş ve çoğunluğu yasa hakkında bilgi sahibi olduğunu dile getirmiştir. Ancak yasanın getirdiği düzenlemelerin neler olduğu sorulduğunda katılımcılardan beklenilen cevapların gelmediği gözlemlenmiştir. Örneğin bu noktada "büyükşehirlerin sayısı arttı" şıkkını sadece katılımcıların 3'te 1'nin cevapladığı görülmüştür. Yani muhtarların kendilerini ilgilendiren yasal mevzuatı bilmedikleri gibi günceli de takip etmedikleri saptanmıştır. Bu durum görevlerini yerine getirirken etkin ve verimli hizmet sunmalarını zedelemektedir. Ancak muhtarlara bu "yasanın mahalle ya da köy yönetimlerine getirdiği düzenlemelerden haberdar mısınız" sorusuna verdikleri cevap, yarısından fazlasının haberdar olduğu yönündedir. Fakat bu yasanın mevcut durumlarında bir değişiklik yaratmadığını savunanlar olduğu gibi yasayla birlikte belediyeden hizmet aldıklarını ve getirilen vergilerden dolayı kırsal yerlerdeki mahallelerde yaşayanların şehirlere göç ettikleri şeklinde değişiklik yarattığını savunanlar da olmaktadır. Genele bakıldığında değişiklik olmadığını savunan kesimin şehir merkezine yakın mahalleler olduğu görülmüştür. Bu değişikliğin zaten buradaki yerler için olumlu olduğu ve bu yerlerin şehirlere sağlanan imkânlardan yararlandıkları saptanmıştır. Bu noktada yasanın kırsal alanda yer alan mahalleler için sorun teşkil ettiği saptanmıştır.

6360 sayılı Yasanın muhtarlar üzerinde yarattığı bir diğer etki ise hizmetlere yönelik taleplerin karşılık bulması noktasında olmuştur. Çünkü katılımcılar 6360 sayılı yasa sonrasında il özel idaresinden ziyade belediyeden hizmet almalarını olumlu karşılanmaktadırlar. Ancak bunun sonucunda da belediyede işlemlerin çok uzun sürmesinden ve sonucun gecikmesinden yakındıkları görülmüştür. Özellikle de kırsal mahalleler bu durumu sıklıkla dile getirmekte, muhtarlar bu yerlere belediyenin çok uzak kaldığını belirtmekle birlikte hizmetin geciktiği de ifade edilmektedir.

Yine kırsal alandaki mahallelerin hala altyapı, yol, ulaşım noktasında sıkıntılar yaşadıkları buna karşılık merkeze yakın mahallelerin ise ulaşım, alt yapı gibi konularda sıkıntıların kalmadığı tam tersi ulaşım noktasında olumlu sonuçlar aldıklarını belirtmişlerdir. Bu noktada 6360 sayılı yasanın kırsal alandaki mahallelerde yarattığı bu etkinin ortadan kaldırılmasına yönelik çalışmalar yapılmalıdır. Zaten muhtarlara özellikle de kırsal alan 
yoğunluğu fazla olan büyükşehir belediyeleri düşünüldüğünde muhtarın kimliğini güçlendirmeye yönelik çalışmalar yapılması gerektiği konusuna neredeyse tamamın da katıldığı görülmüştür. Ayrıca bu yerlerde bulunan muhtarların yetkilerinin artırılması ve 6360 sayılı yasanın bu alanlara yönelik düzenlemelerinde revize yapılması gerektiği görüşü de öne çıkan görüşler arasındadır. Yine bu kapsamda kırsal alanlarda bulunan mahalleler için belediye şubeleri/ ilçe düzeyinde muhtarlar kurulu benzeri bir yapılanmaya gidilerek taleplerin bu birimlere taşınması ve bu birimler aracılığıyla hizmetin alınması gerektiği mevcut sorunlara çözüm olabilir niteliktedir.

Köy yönetimlerinin Türk idari yapılanmasındaki yeri ve geçmişi uzun yıllara dayanmakta ve köy muhtarları da bir yerel yönetim birimi olan köylerin organı ve tüzel kişiliğin de temsilcisi konumundadır. Ancak mahalle muhtarı olarak devam etmeleriyle birlikte bir saygınlıklarının kalmadığını, itibar kaybı yaşadıklarını ve köy muhtarıyken daha değerli görüldüklerini dile getirmişlerdir. Bunun altında yatan sebepler çok çeşitli olmakla birlikte temel olarak köylerin bir yerel yönetim organı olması, tüzel kişiliğe, personele ve bütçeye sahip olmasıdır. Çünkü mahalleler yetki, görev ve sorumluluk noktasında köy muhtarlarından geri planda kalmakta aracı/temsilci bir birim olmaktan öteye gidememektedir. Muhtarların hayatında böyle bir değişim yaşanmasına sebebiyet veren yeni durum mahallelinin hayatında ise bir değişime neden olmadığ 1 alandan elde edilen bilgiler dâhilindedir. Hatta köyün mahalleye dönüşmesiyle birlikte eski köy/ yeni mahallede vergilerin yükseldiğini, tarım ve hayvancılık yapamaz olduklarını, orman köylerinin zarar gördüğü ve bu durumdan olumsuz etkilendiklerini dile getirmişlerdir.

Ayrıca özellikle de kırsal alanlar söz konusu olduğunda bu gibi yerlerde kente ulaşımın çok zor sağlandığı ve kırsal alanlar için kentleşmenin de mümkün olmadığı zaten bunun kırsal alanın ruhuna aykırı olduğu bundan dolayı burada yaşayanların kendini kentli gibi hissedemediği ya da kanunla kentleşebilmek gibi söylemlerinin doğru olmadığı görülmektedir. Hala bazı mahallelerde altyapı sorununun yaşanması bu görüşü destekler niteliktedir. Yine katılımcıların düşüncelerinden hareketle yeni mahallelerin kente yakın olanlarında 6360 sayılı Yasa sonrasında memnuniyet seviyesinin arttığı ancak kentten uzak olanlarda ise memnuniyet seviyesinin azaldığı da saptanmıştır. Bundan dolayı katılımcıların neredeyse yarısından fazlası köyünün mahalleye dönüşmesini olumsuz değerlendirmekte ve köyün mahalleye dönüşmemesi gerektiğini savunmaktadır. Çünkü yeni durumla birlikte çalışmada da ifade edildiği gibi pek çok sorunla karşılaşıldığı belirtilmiştir.

Türkiye'nin 7 farklı coğrafi bölgesinden seçilerek bir anket çalışması uygulanan 8 farklı ilde -ki bunların hepsi büyükşehir belediyesine sahip yani 6360 sayılı yasadan etkilenen iller olmakta- yukarıda da detaylı bir şekilde belirtildiği gibi 6360 sayılı Yasanın muhtarları özellikle de kırsal alanda yer alan muhtarları olumsuz etkilediği saptanmıştır. Muhtarların bu yasaya karşı tavrı kendi şartlarına uygun olarak Yasanın yeniden revize edilmesi yönünde olmuş hatta eğer mevcut durumun böyle gitmesi durumunda köy muhtarıyken sahip oldukları yetkinin tekrar kendilerine verilmesi gerektiğini de dile getirmişlerdir.

Elde edilen bulgulardan hareketle çeşitli çıkarımlara gidilebilmek mümkün olmakla birlikte teoriye göre hazırlanmış olan alan araştırmasını da destekler nitelikte çeşitli öneriler getirmek ve tartışmalar yürütmek de mümkündür. Bu doğrultuda yukarıda anlatılanlara ek olarak;

- Mahalleyi ilgilendiren kanunların revize edilip günün koşullarına ve 6360 sayılı Yasaya uyumlu hale getirilmesi,

- Eski köy/yeni mahallelerin iki kategoriye ayrılmaları (kırsal mahalleler ve kentsel mahalleler olmak üzere),

- Muhtarların 6360 sayılı yasal düzenlemenin mantığını anlamadıklarının tespit edilmesi üzerine bu konuda daha önce de çalışmada dile getirilen kapsamlı bir eğitime tabi tutulmaları gerekliliği,

- Kentsel alanlarda yer alan eski köy/yeni mahalle muhtarlıklarının 6360 sayılı Yasadan olumsuz etkilenmedikleri hatta tam tersi bu uygulamanın olumlu etkiler yarattığını düşündükleri için bu yerlerin yönetim noktasında önceki mahalleler gibi durumlarını sürdürmeleri,

- Özellikle de kırsal alanlarda yer alan muhtarlara, kırsal alanın yönetiminin zorluğundan dolayı, köy muhtarlarının sahip olduğu yetkilerinin tamamının verilmesi ya da belli bir ölçüde serbestiyet tanınması,

- Kırsal alanlarda yer alan yeni mahalleler için köylere hizmet götürme birliklerinin yeniden günün koşullarına cevap verecek şekilde revize edilmesinin ardından faaliyete geçirilmesi,

- KÖYDES gibi KIRDES projelerinin de bu yerlerde yaygınlaştırılmasının sağlanması belirtilen sorunların çözümünde önemli bir unsur olarak görülmektedir. 
- Kırsal alanda hizmet bekleyen eski köy/ yeni mahallelere daha kaliteli hizmet sunabilmek ve hizmeti zamanında ulaştırabilmek için büyükşehir ve ilçe belediyelerce bu alanlara özgü çalıştırılacak birimler oluşturulmalı ve kırsal alana gidecek hizmetler için ayrı bir bütçe tahsisi yapılmalıdır.

- Kırsal alanda yapılan tarım ve hayvancılık faaliyetlerinin olumsuz etkilenmemesi adına köy tüzel kişiliğine ait olan mera, çayır, tarla gibi alanların belediyelerin yetkisi ile satılması ve kiralanması durumlarında hayvancılık ve tarımla uğraşanların haklarının korunması şarttır.

\section{KAYNAKÇA}

AYYILDIZ, Merve, ÇIÇEK, Adnan ve AYYILDIZ, Bekir (2016), "6360 Sayılı Büyükşehir Yasasının Kırsal Kesime Olan Etkileri”, Nevşehir Bilim ve Teknoloji Dergisi, S.(TARGID Özel Sayıs1), ss.280-285.

BAYRAMOĞLU ALADA, Adalet (2000), "Dönüşüme Açılan Kapı: "Mahalle", Yerel Yönetimler Sempozyumu Kitabı, TODAİ Enstitüsü Yerel Yönetimler Araştırma ve Eğitim Merkezi Yayını, Ankara, ss.147- 166.

BAYRAMOĞLU ALADA, Adalet (2002), "Kentsel Yönetime Katılımda 'Mahalle”, E-Makale, http://www.yayed.org/uploads/yuklemeler/inceleme-27.pdf (Erişim Tarihi: 09.10.2017).

BEK, Nahit (2013), “Bir Yerleşim ve Yönetim Birimi Olarak Türkiye’de Mahalle”, Yayınlanmamış Yüksek Lisans Tezi, Onsekiz Mart Üniversitesi Sosyal Bilimler Enstitüsü, Çanakkale.

CIHANGİR ÇAMUR, Kübra (2002), "Köy Yönetimi ve Mekânsal Planlama: Köy Yapısının Sürdürülebilirliği”, Amme İdaresi Dergisi, S.35(4), ss.83-102.

ÇELIKK, M. Lamih ve ALTIPARMAK, Cüneyd (2013), Hukuki Açıdan 100 Soruda Yeni Büyükşehir Belediye Modeli, Seçkin Kitabevi, İstanbul, 2. Baskı.

DİK, Esra (2014), “6360 Sayılı Kanun Bağlamında Köylerin Mahalleye Çevrilmesi Sorunu”, Mülkiye Dergisi, S.38(1), ss.75-102.

ERYILMAZ, Bilal (1988), "Türkiye'de Köy ve Mahalle Muhtarlıklarının Ortaya Çıkışı ve Gelişimi”, Türk İdare Dergisi, S.378, ss.465-478.

GÖKYURT, Fatih, KINDAP, Ahmet ve SARI, Volkan İdris (2015), "Türkiye İçin Yeni Bir Şehir Tanımı Gerekli Mi?", Çağdaş Yerel Yönetimler Dergisi, S.24(1), ss.1-32.

GÖZLER, Kemal ve KAPLAN, Gürsel (2016), İdare Hukuku Dersleri, Ekin Basın Yayın Dağıtım, Bursa, 18. Bask1.

GÜNDÜZÖZ, İlker (2011), "Kırsal Kalkınma Ekseninde KÖYDES Projesi ve Köy Reformu”, Türk İdare Dergisi, S.471, ss.117-142.

KAVRUK, Hikmet (2004), Köy ve Mahalle: Yerleşim ve Yönetim Birimi, Odak Yayıncılık, Ankara.

KILINÇ ÜRKMEZ, Gökçen ve ZENGIN ÇELIK, Hayat (2016), "6360 Sayılı Yasayla Mekânsal İlişki Sisteminin Kır-Kent İkileminde Yeniden Yapılanışı ve Yerel Yönetimler: Kayseri İli Örneği”, Çağdaş Yerel Yönetimler Dergisi, S.25(3), ss.69-94.

OZANKAYA, Özer (1971), “Köyde Toplumsal Yapı ve Siyasal Kültür”, Amme İdaresi Dergisi, S.4(1), ss.3140.

ÖZÇAĞLAR, Ali (1995), “Türkiye’nin İdari Coğrafyası Bakımından Köy, Bucak, İlçe, İl ve Belde Kavramları Üzerine Düşünceler”, AÜDTCF Coğrafya Araştırmaları Dergisi, S.12, ss.7-24.

PALABIYIK, Hamit ve ATAK, Şermin (2000), “İzmir Büyükşehir Bütününe Mahalle Yönetimi”, Yerel Yönetimler Sempozyumu Kitabı, TODAİ Enstitüsü Yerel Yönetimler Araştırma ve Eğitim Merkezi, Ankara, ss.193-201.

SARI, Muhammed (2014), "442 Sayılı Köy Kanunu Çerçevesinde Cumhuriyet Dönemi Köye Yönelik Çalışmalar”, Tarih Okulu Dergisi, S.7(11), ss.509-534.

ŞENGÜL, Ramazan (2016), Yerel Yönetimler, Umuttepe Yayınları, Kocaeli, 6. Bask1. 
TEKIN, Ömer Faruk (2016), “6360 Sayılı Yasanın Büyükşehirlere Bağll İlçeler Bağlamında Getirdiği Değişim: Bozkır Illçesi Örneği”, Uluslararası Sempozyum: Geçmişten Günümüze Bozkır, 6-8 Mayıs 2016, Konya, ss.1245-1262.

TEZCAN, Mahmut (1970), “Sosyolojik Yönden Köy”, Amme İdaresi Dergisi, S.3(2), ss.151-182.

http://www.academia.edu/10182201/6360_SAYILI_KANUN_UN_UYGULAMASINDA_K\%C3\%96Y_L\%C3 \%9C_M\%C3\%9C_MAHALLE_L\%C4\%B0_M\%C4\%B0_KATIL_A_MAYANLAR_A\%C3\%87ISIND AN_B\%C4\%B0R_DE\%C4\%9EERLEND\%C4\%B0RME (Erişim Tarihi: 22.10.2018).

http://www.yayed.org/id261-yayed-gorusu/buyuksehir-tasarisi-hakkinda-yayed-gorusu-11-ekim2012.php\#.W87ipPkzbIV (Erişim Tarihi: 23.10.2018).

https://www.icisleri.gov.tr/mahalli-idareler-genel-mudurlugu (Erişim Tarihi: 30.07.2018). 